\title{
Chapter 2 \\ Evolution of Immigration-Control Policies in France, Italy, and Spain
}

\subsection{Policy Evolution in Multiple Contexts of Reception}

Senegalese migration is a useful case to study because Senegalese migrants are present in many different contexts of reception. They have long migrated to destinations within Africa, including neighboring countries such as the Gambia and Guinea and more-distant destinations such as Angola, the Democratic Republic of the Congo, and South Africa (Bredeloup 1993). While France was the main destination of Senegalese intercontinental emigration during most of the twentieth century, Senegalese migrants have since diversified their mobility to include many countries in Europe, North America, and Asia. Indeed, most Senegalese who travel abroad can recount stories of meeting other Senegalese in the markets of Nairobi, the cafés of Paris, the New York subway, or the streets of Bangkok.

This book takes advantage of part of this diversity of destinations to examine how variation in the socio-legal features of different contexts of reception creates complex trajectories of legal status for this intrepid group of migrants and will link different forms of legal status to the migrants' integration in the destination society and their ongoing participation in the development of their origin communities. While many different destinations could have been considered, this book and the data-collection project on which it is based chose to focus on France, Italy, and Spain. These three countries account for approximately $45 \%$ of all Senegalese migrants residing abroad (Beauchemin and González-Ferrer 2011). While they are all developed countries in the European Union, variations in their historical relationship with Senegal, the evolution of their immigration-control policies, their experiences in receiving immigrants, and their economies all create different configurations of legal status and possibilities of irregularity.

France is of obvious interest as the former colonial power in Senegal. Research has shown that links of language, transportation, and economic exchange forged during colonial times underlie many migration systems across the world (Kritz et al. 1992), and the migration patterns between Senegal and France are no exception to 
this rule (Garson 1992). No understanding of Senegalese migration would be complete without an accounting of Senegalese migration to France. In addition, the colonial relationship had important implications for the socio-legal parameters structuring the legal statuses of Senegalese migrants in France in the postindependence period. During the colonial era, Senegalese born in the so-called quatre communes of St. Louis, Gorée, Rufisque, and Dakar had a form of French citizenship, which Senegalese deputies to the French Assembly in the early twentieth century sought to reinforce via military service during the two World Wars. This "blood debt" later served as a pillar in the fight for secure legal status for Senegalese sans papiers in France (Coquery-Vidrovitch 2001; Mann 2003).

The colonial relationship also directly structured post-independence immigrationcontrol measures in France. The former colonial power sought to defend the vestiges of colonial privileges of free entry and establishment in Senegal for its own citizens, and thus created a preferential bilateral immigration-control regime with Senegal that facilitated the entry and eventual settlement of Senegalese in France. This preferential regime was largely at odds with the ordinance of 1945 that sought to recruit immigrants from culturally similar southern European countries for economic and demographic purposes (Spire 2005), which nonetheless established the framework for a restrictive immigration-control regime. While French policymakers immediately and constantly chipped away at the preferential regime between France and Senegal, it officially lasted until the early twenty-first century, and the evolution towards a closed and restrictive regime more in line with national immigration law was instrumental in encouraging both the settlement of formerly-mobile Senegalese migrants and their families in France and the exploration of new destinations such as Italy, Spain, Greece, and the United States.

The new destinations of Italy and Spain provide counterpoints to the experience of Senegalese migration to France. Both Italy and Spain have long histories as countries of emigration; indeed, both provided many migrants to France in the postWorld War II period. In contrast, these countries' experience receiving immigrants is much more recent. While France has been a country of immigration (in demographic if not cultural terms) since the late nineteenth century, Spain and Italy only started receiving migrants in the 1990s. As a result, Spanish and Italian apparatuses of immigration control are much more recent. Neither had any national-level immigration policy with the normative status of legislation until the 1990s, and the impetus for this legislation came from the European Union integration instead of any overriding internal concern with immigration; indeed, both countries still had low levels of immigration at the time of their respective laws (González-Enríquez 2009; Sciortino 1999).

Immigration-control policies in both southern European countries have since developed in a restrictive fashion, marked by an overriding concern with border control along Mediterranean coastlines. Indeed, these countries have reputations for being the clandestine port of entry for migrants from less-developed neighboring countries such as Morocco and Tunisia, and these North African countries have themselves transformed into transit points for migrants from sub-Saharan African countries (including Senegal) (de Haas 2007). Italy and Spain thus have a different 
history of immigration-control policies than France and face different immigrationcontrol challenges than their northern neighbor.

In addition, these two new destinations do not have any meaningful historical links with Senegal. Neither country had any colonial enterprises in Senegal or anywhere in West Africa, nor do they share cultural or linguistic links with Senegal. Unlike many other European countries of immigration, they also did not engage in post-war labor recruitment in former colonies. Research suggests that Senegalese migration to southern European countries started as a result of the confluence of immigration-control policies in the traditional and new destinations (Fall 2005; Kaag 2008; Tall 2008). France was tightening the preferential bilateral regime with Senegal in the 1980s and 1990s at the same time that Italy and Spain were starting to come to grips with increasing numbers of immigrants within their borders.

One of the first immigration-policy measures that the southern European countries pursued was regularization programs, which reportedly attracted Senegalese migrants from France who were finding it increasingly difficult to gain and maintain secure legal status (Fall 2005; Kaag 2008; Schoumaker et al. 2013; Tall 2008). Research also points to the role that the economies of these southern European countries played in attracting Senegalese migrants. Both countries have a morerobust informal sector than France, wherein migrants can find gainful employment without competing with natives or the need for legal authorization (GonzalezEnríquez and Triandafyllidou 2009; Reyneri 1998). Many Senegalese thus turned to informal entrepreneurial activities in northern Italy or informal agricultural labor in Spain as ways to accumulate the resources they were increasingly unable to find in France (Ebin 1992; di Friedberg 1993; Riccio 2001).

Immigration-control policies have thus played an important role in structuring the migration strategies and incorporation of Senegalese migrants in France, Italy, and Spain. This chapter will trace the evolution of those policies and the mechanisms of external and internal control (Brochmann 1999) they define (see Table 2.1 for the terms for visas, residence permits, and work permits in France, Italy, and Spain). It will examine the consequences policies and mechanisms of control have had for trajectories of legal status of Senegalese migrants, and in so doing will underline that the legal status that migrants possess is a "relational product" (Sciortino 2004): states create the legal parameters that define pathways to regular or irregular legal status.

Table 2.1 Terms for visa, residence permit, and work permit in France, Italy, and Spain

\begin{tabular}{l|l|l|l}
\hline Authorization & France & Italy & Spain \\
\hline Visa & Visa & Visto & Visado \\
\hline $\begin{array}{l}\text { Residence } \\
\text { permit }\end{array}$ & $\begin{array}{l}\text { Titre de séjour, carte de } \\
\text { séjour, carte de résident, } \\
\text { permis de résidence }\end{array}$ & $\begin{array}{l}\text { Permesso di soggiorno, } \\
\text { carta di soggiorno }\end{array}$ & $\begin{array}{l}\text { Permiso de residencia, } \\
\text { permiso de estancia }\end{array}$ \\
\hline Work permit & $\begin{array}{l}\text { Titre de travail, carte de } \\
\text { travail, autorisation de travail, } \\
\text { permis de travail }\end{array}$ & $\begin{array}{l}\text { Autorizzazione al } \\
\text { lavoro }\end{array}$ & $\begin{array}{l}\text { Autorización } \\
\text { administrativa para } \\
\text { trabajar }\end{array}$ \\
\hline
\end{tabular}




\subsection{France}

\subsubsection{Colonial "Assimilation" and Citizenship}

Senegalese migrants long benefitted from a special immigration-policy regime that traces its roots to the earliest days of the French colonial administration in Senegal. The French established their first permanent settlement in what is now Senegal on an uninhabited island in the mouth of the Senegal River in 1659. Originally set up as a trading post to take advantage of commercial opportunities along the river, Saint-Louis - named after King Louis XIV — eventually became the capital of the French colony of Senegal (Crowder 1967). A small community of French traders and mixed French-African "habitants" developed Saint-Louis into a commercial hub. The rights of the habitants as French citizens were recognized by the French revolutionary government in 1791, and a law in 1833 guaranteed the civil and political rights of all free-born or freed persons born in French colonies (CoqueryVidrovitch 2001). The revolution of 1848 further entrenched these rights by giving Senegal a seat in the French parliament and allowing Senegalese born in the quatre communes (four towns) of Saint-Louis, Gorée, Rufisque, and Dakar-called originaires (natives) — to vote as French citizens (Coquery-Vidrovitch 2001).

This extension of rights to Senegalese originaires was part of the French policy of colonial "assimilation." Crowder (1967) notes that "assimilation" can have many meanings when it comes to French colonial policy, but argues that its application in Senegal included political assimilation to France through elected representation in the French assembly; administrative assimilation through the creation of a conseil général and municipal councils for the governance of Senegal modeled on similar structures for departmental and municipal governance in France; and the extension of French educational facilities. Assimilation was also extended on the personal level by according originaires the status of French citizens. Originaires thus faced a much more lenient administration than residents of the rest of Senegal and other nations of Afrique Occidentale Française (AOF), who, as sujets (subjects), were subject to military rule, violence, cash taxes, and forced labor (Crowder 1967). Originaires were subject to French civil law unless they opted to remain under the traditional system of Islamic law with reference to civil disputes, matrimony, divorce, inheritance and land.

This bifurcation of French citizenship provoked a reaction on the part of the French, who felt that to be included in the French polity as a French citizen required a submission to French civil law and related institutions, such as monogamous marriage (Crowder 1967). As a result, French legislators and colonial administrators often attempted to redefine the boundaries of French citizenship and nationality in ways that would exclude the originaires from the full exercise of their rights (Coquery-Vidrovitch 2001). 


\subsubsection{Link Between Colonial-Era Policies and Migration}

The colonial-era policies depriving most Senegalese of political rights directly gave rise to migration. French colonization of Senegal was part of the partition of Africa by the major European powers. This partition drove expansion of capitalism, facilitating the extension of global markets and capital into African societies. Amin (1995) argues that this expansion allowed the colonizing countries to achieve the main capitalist goal of obtaining cheap export goods. He outlines the development of a system of colonial exploitation in various parts of the continent, including the extraction of raw materials (gold and diamond mining in South Africa, copper in Northern Rhodesia and Katanga) and the production of tropical agricultural products (palm oil in the Gold Coast, cacao in the Ivory Coast, and groundnuts in Senegambia).

A key component of these export systems' functioning was the creation and exploitation of labor from the "reserve" of indigenous Africans such as the French sujets. Through strategic political alliances, the subordination of traditional commercial relationships, monetary taxation of agricultural products, and forced labor, these colonial systems created a proletarianized labor force. Traditional society was thus transformed, Amin argues, into a "purveyor of temporary or permanent migrants on a vast scale" (1995: 33).

In colonial Senegal, the policies that created the statuses of "originaire" and "sujet" also undergirded the system of forced labor and taxation. Findley et al. (1995) argue that the colonial system disrupted the traditional agricultural economy of the Senegal River valley by instituting a head tax that induced peasants- the "sujets" of the French colonial legal system-to work in the groundnut and cotton plantations. Paying the monetary tax meant selling animals or portions of the harvest or seasonally migrating to the coastal colonial plantations to earn the money for the tax by selling labor. The French colonial regime also resorted to forced laborthe "navetanat" - to ensure a supply of labor on the groundnut plantations of the Sine-Saloum. The French colonial system in Senegal thus accomplished its goals of integrating the region into a monetized market economy and producing a surplus for export. The introduction of cash crops, the development of rail lines, and the investment in coastal cities all further eroded the pre-existing peasant modes of social and economic organization and contributed to a growing pool of potential emigrants. Furthermore, the internal mobility induced by the navetanat would eventually translate into international migration towards France (Findley et al. 1995).

While the status of sujet directly created internal and, eventually, international mobility among a portion of the Senegalese population, the status of originaire would also lay the foundations for future migration towards France. Blaise Diagne, who served as the first African deputy from Senegal to the French assembly from 1914 to 1937, attempted to reinforce the eroded political rights of originaires during World War I. He shepherded a series of laws through the French assembly that allowed Senegalese soldiers, who had heretofore served in the French military in 
segregated units called the tirailleurs sénégalais, to serve in regular units alongside French soldiers. The laws also stipulated that all natives of the quatre communes and their descendants would be French citizens subject to mandatory military service (Coquery-Vidrovitch 2001).

Senegalese and other natives of French West Africa fulfilled this obligation by serving as shock troops in World War I and fighting with General de Gaulle's forces in North Africa and Italy in World War II; West African troops even fought in French conflicts in Indochina and Algeria following World War II (Mann 2003). Following the wars, many soldiers from Senegal and other African territories enlisted in the French merchant marine and settled clandestinely in port cities such as Bordeaux, Toulon, Marseille, Le Havre, and Dunkerque (Manchuelle 1997). Although a boon for navigation companies looking for low-skill workers on boats and docks, the presence of these Africans incited public concern about security and public order (Fall 2005).

Despite this "blood debt" incurred by France, the French policy of assimilation existed mostly as an imaginary ideal, as colonial administrators consistently made attempts to limit claims to French citizenship and reinforce African inferiority (Coquery-Vidrovitch 2001; Crowder 1967). Despite these efforts to limit the ability of Senegalese to access the full rights French citizenship while burdening them with some of the onerous responsibilities, the precedent of political and personal assimilation created a special status for Senegalese that the French would continue to acknowledge in the preferential regime that followed independence in 1960 and that would directly create the conditions for migration to France.

\subsubsection{Post-War Reconstruction and the Importation of Foreign Labor}

Senegalese migration to France began in earnest following World War II as demand for unskilled foreign labor increased during the French economic boom of the 1950s and 1960s. France was one of the countries that turned to labor recruitment and importation to meet the challenges of post-war rebuilding in the context of labor shortages. Although the vast majority of imported laborers came from southern Europe, many also came from France's African colonies. Employers recruited workers in the rural Senegal River valley to work in flexible and low-skill jobs in the auto, textile, and hotel industries (Fall 2005). A system called noria ensured that circularity was the norm: Senegalese workers stayed in France for a number of years before returning home to send a family member to take their places (Tall 2008). Most migrants were primarily interested not in settling in France but in sending funds to their families in Senegal (Fall 2005). This voluntary separation from the host society found its residential complement in the foyers de travailleurs migrants, lodging provided by employers or municipalities that ensured that migrants were kept in close proximity to each other but separated from French society. 


\section{The General Regime of the Ordinance of 1945}

While Senegalese migrants were not initially subject to general immigration policy in postwar France, this so-called "general regime" provided the framework for the general evolution over more than 50 years of the bilateral accords providing juridical context for Senegalese migrants' legal status. The main pillar of postwar French immigration policy was the Ordonnance $n^{\circ} .45-2658 d u 2$ Novembre 1945, relative à l'entrée et au séjour des étrangers en France. This ordinance organized labor migration under the auspices of the Office national de l'immigration (ONI) (see Table 2.2 at the end of Sect. 2.2 for a synthesis of the evolution of immigration policy in France). Employers wishing to hire foreign labor were formally required to submit a request to ONI, which would fill the post with a qualified foreigner. The ordonnance further stipulated that foreigners entering for work needed to do so under cover of a visa and with a government-approved work contract. Upon arrival, migrants needed to apply for a permis de résidence (residence permit) from the Ministry of the Interior and a permis de travail (work permit) from the Ministry of Labor. There were many kinds of residence permits for different types of stay for more than 3 months, but obtaining a residence permit for the purposes of a salaried activity required the presentation of an official work contract. After obtaining a temporary authorization to stay in France, the migrant would then receive a work permit (Spire 2005).

In reality, decisions on the granting of residence and work permits were made by autonomous bureaucrats and were often not coordinated between Ministries, leading to permits of different lengths and the possibility of irregularity in either legal domain of work or residence (Spire 2005). The 1945 ordinance provided the foundations of immigration in policy in France through the end of the twentieth century, and its text was not officially modified until the 1980s. Most changes in immigration policy prior to those modifications thus occurred in administrative circulars issued by various ministries, a method chosen for its flexibility and lack of oversight in representative political bodies (although the Conseil d'Etat could, and occasionally did, weigh in on the constitutionality of these measures).

\section{Decolonization and the Creation of a Preferential Regime}

Senegalese were not initially subject to the general regime following the postwar reorganization of the French colonial system. This system, with its distinction between originaire and sujet, existed until 1946, when, in the aftermath of World War II, France promulgated a new constitution. At this point, all residents of French colonial territories and protectorates were granted French citizenship, which would, in theory, allow free circulation and establishment between the territories of the empire. In practice, colonial administrators did not allow colonial subjects to travel to the metropole, all the while encouraging intra-colony mobility via cash head taxes to assure a steady supply of labor for colonial cash crops, such as peanuts in Senegal (Amin 1972). 
Table 2.2 Synthesis of major immigration measures in France and consequences for migrant irregularity

\begin{tabular}{|c|c|c|}
\hline Date & Name of law & Consequence for irregularity \\
\hline \multirow{3}{*}{$\begin{array}{l}\text { November } \\
2,1945\end{array}$} & \multirow{3}{*}{$\begin{array}{l}\text { Ordonnance } n^{\circ} .45-2658 \text { du } 2 \text { Novembre } 1945 \text {, } \\
\text { relative à l'entrée et au séjour des étrangers en } \\
\text { France }\end{array}$} & Organized labor migration \\
\hline & & $\begin{array}{l}\text { Foreigners entering for work } \\
\text { needed to do so under cover } \\
\text { of a visa and with a } \\
\text { government-approved work } \\
\text { contract }\end{array}$ \\
\hline & & $\begin{array}{l}\text { Residence permit conditional } \\
\text { on presentation of work } \\
\text { contract }\end{array}$ \\
\hline \multirow[t]{2}{*}{$\begin{array}{l}\text { October } \\
13,1946\end{array}$} & \multirow[t]{2}{*}{ Constitution of the Fourth Republic } & $\begin{array}{l}\text { French citizenship granted to } \\
\text { all residents of French } \\
\text { colonial territories and } \\
\text { protectorates }\end{array}$ \\
\hline & & Creation of French Union \\
\hline \multirow[t]{2}{*}{$\begin{array}{l}\text { October 4, } \\
1958\end{array}$} & \multirow[t]{2}{*}{ Constitution of the Fifth Republic } & $\begin{array}{l}\text { Creation of the French } \\
\text { Community }\end{array}$ \\
\hline & & Independence of Guinea \\
\hline $\begin{array}{l}\text { April 18, } \\
1956\end{array}$ & $\begin{array}{l}\text { Circulaire du Ministère du Travail et des Affaires } \\
\text { Sociales }\end{array}$ & $\begin{array}{l}\text { Permitted post-arrival } \\
\text { regularization of workers }\end{array}$ \\
\hline $\begin{array}{l}\text { July 19, } \\
1960\end{array}$ & Convention d'établissement & $\begin{array}{l}\text { Senegalese free to enter, } \\
\text { reside, and work in France }\end{array}$ \\
\hline \multirow[t]{2}{*}{$\begin{array}{l}\text { January 21, } \\
1964\end{array}$} & \multirow[t]{2}{*}{ Bilateral treaty } & $\begin{array}{l}\text { Senegalese needed only an } \\
\text { identity card and proof of } \\
\text { vaccinations to enter France }\end{array}$ \\
\hline & & $\begin{array}{l}\text { Formal work was subject to } \\
\text { an employment contract } \\
\text { approved by the Ministry of } \\
\text { Labor and a pre-departure } \\
\text { medical exam }\end{array}$ \\
\hline $\begin{array}{l}\text { August 21, } \\
1967\end{array}$ & Ordonnance no 67-707 & $\begin{array}{l}\text { Reinforcement of medical } \\
\text { control for work }\end{array}$ \\
\hline $\begin{array}{l}\text { April 29, } \\
1968\end{array}$ & Décret d'application 68-399 & $\begin{array}{l}\text { Reinforcement of medical } \\
\text { control for work }\end{array}$ \\
\hline $\begin{array}{l}\text { July } 29 \text {, } \\
1968\end{array}$ & Circulaire du ministère des Affaires sociales & $\begin{array}{l}\text { Post-arrival regularizations of } \\
\text { workers scaled back }\end{array}$ \\
\hline $\begin{array}{l}\text { February } \\
25,1970\end{array}$ & $\begin{array}{l}\text { Note du } 25 \text { février } 1970 \text { de la Direction centrale } \\
\text { des Renseignements généraux consacrée au " } \\
\text { renforcement du contrôle des ressortissants } \\
\text { africains se présentant en qualité de touriste » }\end{array}$ & $\begin{array}{l}\text { Africans entering as tourists } \\
\text { integrrogated at border and } \\
\text { issued identity document }\end{array}$ \\
\hline \multirow{2}{*}{$\begin{array}{l}\text { January 24, } \\
1972\end{array}$} & \multirow[t]{2}{*}{ Circulaire Marcellin-Fontanet } & Limited regularizations \\
\hline & & $\begin{array}{l}\text { Combined residence/work } \\
\text { permit }\end{array}$ \\
\hline $\begin{array}{l}\text { March 28, } \\
1974\end{array}$ & Bilateral treaty & $\begin{array}{l}\text { Required residence permit } \\
\text { for stays greater than } \\
3 \text { months }\end{array}$ \\
\hline
\end{tabular}


Table 2.2 (continued)

\begin{tabular}{|c|c|c|}
\hline Date & Name of law & Consequence for irregularity \\
\hline $\begin{array}{l}\text { July 3, } \\
1974\end{array}$ & Decision by the Council of Ministers & $\begin{array}{l}\text { Suspension of labor } \\
\text { immigration (with } \\
\text { administrative circulars } \\
\text { following on July 5) }\end{array}$ \\
\hline $\begin{array}{l}\text { November } \\
30,1974\end{array}$ & $\begin{array}{l}\text { Circulaire n. 74-628, en date du } 30 \text { novembre 1974, } \\
\text { du Ministre d'Etat, Ministre de l'Intérieur, et la } \\
\text { circulaire n. 21-74, en date du } 30 \text { novembre 1974, } \\
\text { du Secrétaire d'Etat auprès du Ministre du Travail } \\
\text { relatives aux conditions de séjour et d'emploi des } \\
\text { ressortissants des pays d'Afrique au Sud du Sahara } \\
\text { autrefois sous administration française }\end{array}$ & $\begin{array}{l}\text { Required residence permit } \\
\text { for all nationals of sub- } \\
\text { Saharan African states } \\
\text { formerly under French } \\
\text { administration }\end{array}$ \\
\hline \multirow[t]{3}{*}{$\begin{array}{l}\text { January } 1, \\
1980\end{array}$} & \multirow[t]{3}{*}{ Loi Bonnet } & $\begin{array}{l}\text { Tightened entry requirements } \\
\text { by requiring repatriation } \\
\text { guarantees }\end{array}$ \\
\hline & & $\begin{array}{l}\text { Declared the entry or } \\
\text { residence of "illegal" } \\
\text { migrants to be a threat to } \\
\text { public order }\end{array}$ \\
\hline & & $\begin{array}{l}\text { Facilitated expulsions of } \\
\text { undocumented migrants }\end{array}$ \\
\hline $\begin{array}{l}\text { February 1, } \\
1981\end{array}$ & Loi Peyrefitte & $\begin{array}{l}\text { Allowed preventative identity } \\
\text { checks of suspected } \\
\text { undocumented migrants }\end{array}$ \\
\hline \multirow[t]{3}{*}{$\begin{array}{l}\text { October } \\
29,1981\end{array}$} & \multirow[t]{3}{*}{$\begin{array}{l}\text { Loi } n^{\circ} 81-973 \text { du } 29 \text { octobre } 1981 \text { relative aux } \\
\text { conditions d'entrée et de séjour des étrangers en } \\
\text { France }\end{array}$} & $\begin{array}{l}\text { Eliminated provisions of the } \\
\text { loi Bonnet allowing the } \\
\text { expulsion of minors and } \\
\text { parents of French children }\end{array}$ \\
\hline & & Return incentives abolished \\
\hline & & Regularization program \\
\hline \multirow[t]{2}{*}{$\begin{array}{l}\text { July } 17 \\
1984\end{array}$} & \multirow[t]{2}{*}{ Loi Dufoix } & $\begin{array}{l}\text { Formalized single residence/ } \\
\text { work permit }\end{array}$ \\
\hline & & $\begin{array}{l}\text { Introduced } 10 \text {-year } \\
\text { permanent residence card } \\
\text { with automatic renewal }\end{array}$ \\
\hline \multirow[t]{2}{*}{$\begin{array}{l}\text { September } \\
9,1986\end{array}$} & \multirow{2}{*}{$\begin{array}{l}\text { Loi Pasqua (I): loi no 86-1025 du } 9 \text { septembre } 1986 \\
\text { relative aux conditions d'entrée et de séjour des } \\
\text { étrangers en France }\end{array}$} & $\begin{array}{l}\text { Facilitated expulsion } \\
\text { procedures }\end{array}$ \\
\hline & & $\begin{array}{l}\text { Restricted access to 10-year } \\
\text { permit }\end{array}$ \\
\hline $\begin{array}{l}\text { September } \\
16,1986\end{array}$ & $\begin{array}{l}\text { Avis relatif à la suspension de certains } \\
\text { engagements internationaux portant dispense de } \\
\text { l'obligation du visa pour l'entrée en France }\end{array}$ & $\begin{array}{l}\text { Suspended the clauses of } \\
\text { bilateral treaties exempting } \\
\text { Senegalese and other } \\
\text { sub-Saharan Africans from } \\
\text { visas for entry to France }\end{array}$ \\
\hline $\begin{array}{l}\text { August 2, } \\
1989\end{array}$ & Loi Joxe & $\begin{array}{l}\text { Eased some of the restrictive } \\
\text { measures of Pasqua law }\end{array}$ \\
\hline
\end{tabular}


Table 2.2 (continued)

\begin{tabular}{|c|c|c|}
\hline Date & Name of law & Consequence for irregularity \\
\hline \multirow[t]{4}{*}{$\begin{array}{l}\text { August 1, } \\
1995\end{array}$} & \multirow[t]{4}{*}{ Bilateral treaty } & $\begin{array}{l}\text { Visas and proof of means/ } \\
\text { return trip required for entry } \\
\text { of Senegalese }\end{array}$ \\
\hline & & \begin{tabular}{|l|}
$\begin{array}{l}\text { Long-stay visa required for } \\
\text { stays of over } 3 \text { months }\end{array}$ \\
\end{tabular} \\
\hline & & $\begin{array}{l}\text { Approved work contract and } \\
\text { long-stay visa required for } \\
\text { entry for employment }\end{array}$ \\
\hline & & $\begin{array}{l}\text { Required a residence permit } \\
\text { for all stays in France } \\
\text { exceeding } 3 \text { months }\end{array}$ \\
\hline \multirow[t]{7}{*}{$\begin{array}{l}\text { August 24, } \\
1993\end{array}$} & \multirow[t]{7}{*}{ Loi Pasqua (II) } & $\begin{array}{l}\text { Made acquisition of French } \\
\text { citizenship more difficult for } \\
\text { children born in France }\end{array}$ \\
\hline & & $\begin{array}{l}\text { Facilitated the expulsion of } \\
\text { undocumented foreigners }\end{array}$ \\
\hline & & $\begin{array}{l}\text { Increased waiting time to } \\
2 \text { years for family } \\
\text { reunification }\end{array}$ \\
\hline & & $\begin{array}{l}\text { Prohibited the regularization } \\
\text { of undocumented migrants } \\
\text { who married a French citizen }\end{array}$ \\
\hline & & $\begin{array}{l}\text { Made the issuance of } \\
\text { residence permits dependent } \\
\text { on the regularity of entry and } \\
\text { prior stay }\end{array}$ \\
\hline & & $\begin{array}{l}\text { Denied re-entry for } 1 \text { year for } \\
\text { expelled foreigners }\end{array}$ \\
\hline & & $\begin{array}{l}\text { Created category of " } n i \\
\text { régularisable ni expulsable" }\end{array}$ \\
\hline \multirow[t]{2}{*}{$\begin{array}{l}\text { April 24, } \\
1997\end{array}$} & \multirow[t]{2}{*}{ Loi Debré } & $\begin{array}{l}\text { Allowed regularization of } \\
\text { "ni...ni" irregular migrants }\end{array}$ \\
\hline & & $\begin{array}{l}\text { Increased the state's } \\
\text { surveillance power of } \\
\text { suspected irregular migrants }\end{array}$ \\
\hline $\begin{array}{l}\text { June 24, } \\
1997\end{array}$ & Circulaire du ministère de l'Intérieur & $\begin{array}{l}\text { Case-by-case regularizations } \\
\text { with provisions for the } \\
\text { adjustment of status of } \\
\text { spouses with irregular status } \\
\text { and children of migrants with } \\
\text { irregular status }\end{array}$ \\
\hline $\begin{array}{l}\text { March 16, } \\
1998\end{array}$ & $\begin{array}{l}\text { Loi Guigou: Loi n } 98-170 \text { du } 16 \text { mars } 1998 \\
\text { relative à la nationalité }\end{array}$ & $\begin{array}{l}\text { Reinstated limited jus soli } \\
\text { citizenship provisions }\end{array}$ \\
\hline
\end{tabular}


Table 2.2 (continued)

\begin{tabular}{|c|c|c|}
\hline Date & Name of law & Consequence for irregularity \\
\hline \multirow[t]{2}{*}{$\begin{array}{l}\text { May 11, } \\
1998\end{array}$} & \multirow[t]{2}{*}{ Loi Chevènement/RESEDA } & $\begin{array}{l}\text { Reformed system of } \\
\text { residence permits to reinforce } \\
\text { rights of migrant families }\end{array}$ \\
\hline & & $\begin{array}{l}\text { Enacted "on the fly" } \\
\text { regularizations for those } \\
\text { proving } 10 \text { years of residence } \\
\text { in France }\end{array}$ \\
\hline \multirow{5}{*}{$\begin{array}{l}\text { November } \\
26,2003\end{array}$} & \multirow{5}{*}{$\begin{array}{l}\text { Loi Sarkozy: Loi } n^{\circ} 2003-1119 \text { du } 26 \text { novembre } \\
2003 \text { relative à la maîtrise de l'immigration, au } \\
\text { séjour des étrangers en France et à la nationalité }\end{array}$} & Eased the expulsion process \\
\hline & & $\begin{array}{l}\text { Increased the period of } \\
\text { detention for irregular } \\
\text { migrants to } 32 \text { days }\end{array}$ \\
\hline & & $\begin{array}{l}\text { Reinstated strict controls on } \\
\text { marriage with a foreign } \\
\text { spouse }\end{array}$ \\
\hline & & $\begin{array}{l}\text { Increased waiting time for } \\
\text { permanent residence permit }\end{array}$ \\
\hline & & $\begin{array}{l}\text { Made issuance of permanent } \\
\text { and family-reunification } \\
\text { permits contingent on } \\
\text { integration }\end{array}$ \\
\hline $\begin{array}{l}\text { November } \\
24,2004\end{array}$ & $\begin{array}{l}\text { Code de l'entrée et du séjour des étrangers et du } \\
\text { droit d'asile (CESEDA) }\end{array}$ & $\begin{array}{l}\text { Consolidated immigration } \\
\text { law }\end{array}$ \\
\hline \multirow[t]{3}{*}{$\begin{array}{l}\text { July } 24, \\
2006\end{array}$} & \multirow[t]{3}{*}{$\begin{array}{l}\text { Loi Sarkozy (II): Loi } n^{\circ} 2006-911 \text { du } 24 \text { juillet } \\
2006 \text { relative à l'immigration et à l'intégration }\end{array}$} & $\begin{array}{l}\text { Allowed for some kinds of } \\
\text { immigration choisie } \\
\text { (high-skilled workers) }\end{array}$ \\
\hline & & $\begin{array}{l}\text { Repealed provision for } \\
\text { regularization of long-term } \\
\text { residents }\end{array}$ \\
\hline & & $\begin{array}{l}\text { Required contrat d'accueil et } \\
\text { d'intégration for family } \\
\text { reunification and permanent } \\
\text { residence }\end{array}$ \\
\hline $\begin{array}{l}\text { September } \\
23,2006\end{array}$ & $\begin{array}{l}\text { Accord entre le Gouvernement de la République } \\
\text { française et le Gouvernement de la République du } \\
\text { Sénégal relatif à la gestion concertée des flux } \\
\text { migratoires }\end{array}$ & $\begin{array}{l}\text { Allowed issuance of } \\
\text { residence permits for } \\
\text { Senegalese with a job offer } \\
\text { (even those irregularly } \\
\text { resident in France) in any of } \\
10 \text { listed professions }\end{array}$ \\
\hline
\end{tabular}

As Senegalese and other African subjects were still part of the French empire and were not considered foreigners, the ordonnance of 1945 thus would not have applied to them if they had sought to work in France. In reality, the colonial system still prevented circulation between the colonies and the metropole, so sub-Saharan African workers were not, at this point, considered as a viable source of metropolitan labor even though they had been considered as a viable source of military manpower during the two World Wars. 
During the post-war era, African political elites were debating the place of their societies in the French colonial system: while some leaders favored ongoing federation with the colonial power and the assimilation to the French polity and nation that it implied, others favored the independence of the colonies as sovereign nationstates. France decided to put the issue to a vote in 1958, when it proposed a new constitution that defined a new Communauté française. France organized a referendum by which colonial territories were free to accept the constitution, and remain within the Communauté, or reject it and become an independent nation-state. Guinea, under the leadership of the trade unionist Sékou Touré, voted resoundingly to reject the constitution and became independent in 1958. Senegal and the other colonial territories remained in the Communauté, but the inexorable momentum was towards independence, which Senegal achieved in 1960, first as a federation with neighboring Mali and subsequently as a fully independent nation-state in 1962.

\subsubsection{The 1960s: The Special Regime of the Bilateral Accord and Widespread Irregularity}

\section{Senegalese Independence, the Preferential Regime, and "Immigration Sauvage"}

France did not block its African territories from becoming independent but was concerned about protecting its colonial interests, giving rise to a series of bilateral treaties with the newly independent countries that defined the legal framework for circulation between and residence in the respective countries. One of the most important treaties was the "Convention d'établissement," which stated that French nationals resident in Senegal had the same rights as Senegalese nationals, and vice versa. This reciprocity, called "assimilation au national", notably guaranteed bilateral freedom of entry and residence and free exercise of economic activities (Dedieu 2011). While in some ways these provisions allowed for the continuation of French colonial citizenship for Senegalese nationals, the motive for this treaty was to protect the rights of French citizens in Senegal (Donovon 1988; Marot 1995). The practice of "assimilation au national" was enacted in a bilateral treaty signed by France and Senegal in 1964 that allowed for free circulation between the two countries and free establishment and exercise of professions for expatriates residing in the foreign country. Senegalese needed only an identity card and proof of vaccinations to enter France, while formal work was subject to an employment contract approved by the Ministry of Labor and a medical exam at the French consulate in Senegal.

While the provisions of this treaty seem remarkably open, at the time it was seen as restrictive: the independence of Senegal and other African colonies had provoked what was seen as an "immigration sauvage" to the metropole, and the French authorities saw the requirement of identity documents, vaccination cards, and work contracts as an effective way to stem this flow (Bergues 1973; Diop 1993). Even 
Senegalese authorities criticized this new flow of emigrants, and imposed an exit visa for Senegalese wishing to travel to France (Kane 2011). Thus, while Senegalese did not need a visa to enter France and did not need a residence permit to reside there, the requirement of an exit visa and of identity documents created the framework for a kind of irregular status. Senegalese without identity documents would often enlist as crew or stow away on France-bound ships and would then enter France clandestinely when the ship docked at Bordeaux or Marseille. These migrants could be considered to have entered irregularly even though no visa was required (Bergues 1973). Senegalese migrants with identity documents would also circumvent the exit-visa requirement by traveling to neighboring African countries to other European countries before traveling to France (Bergues 1973). Senegalese and other former African subjects thus faced legal configurations that created the conditions for irregularity even during this early "preferential" regime (Lochak 1997).

There was increasing concern throughout the 1960s in France about the continued "immigration sauvage" of Senegalese and other sub-Saharan Africans despite their limited presence (Tapinos 1965 estimates the total "very low" sub-Saharan population at 35,000). Reports to the Conseil économique et social in 1964 and 1968 highlighted the deplorable conditions under which many of these migrants lived, and articles in the popular press "discovered" these migrants and likened their situation to modern slavery (Diop 1993). A particular concern was the high rate of tuberculosis among sub-Saharan Africans in France; a series of circulars in 1968 and 1969 thus reinforced the requirements of medical examinations prior to entry for work (Bergues 1973).

In addition to concerns about the health and living conditions of these migrants, there was a growing realization that many of the limited number of Africans residing in France arrived as tourists and subsequently found work and regularized their status after arrival. While the bilateral treaties only allowed Senegalese to enter France for work under cover of a formal work contract, the treaties did not allow Senegalese to be refused employment once in France. The treaties also did not require Senegalese to have a carte de séjour or a permis de travail. As a result, many Senegalese entered France on their identity cards (or those of others if they did not have their own) and simply looked for work once in France. The Ministry of the Interior thus sought to impose the obligation of a carte de séjour on Senegalese and other Africans who were subject to bilateral accords that exempted them from the general requirement to possess such an authorization (Spire 2005).

Unable to convince the Ministry of Foreign Affairs to push for the revision of the treaties, the Ministry of the Interior thus published a "note" in February 1970 instructing border-control agents to interrogate Africans arriving at the border as to their motives for stay and their means of return to their home countries. If admitted, the African "tourist" would then be issued a "notice individuelle pour touriste étranger" (individual notice for foreign tourist) with the tourist's civil status and expected length of stay in France. This document had to be presented to police during identity checks, and formed that juridical basis for expulsion of the perceived increasing number of "clandestine" African migrants (Spire 2005). This immigrationcontrol measure, of questionable legal validity because of the exemption of 
Senegalese from general immigration requirements, thus provided French authorities with a "back door" to combat this unwanted flow and transform migrants who were "regular" from the point of view of the treaties governing their status into "clandestine" migrants with "irregular" status. The French state thus took concrete steps in the 1960s to transform a legal flow of migrants into an irregular one in the pursuit of increased control.

\section{The General Regime: Post-facto Regularization as the Norm}

At the same time that pressure was mounting to submit Senegalese and other former subjects from sub-Saharan Africa under stricter control, the general immigrationcontrol regime started to come under criticism. During the post-war period-known in France as les trente glorieuses-irregularity among immigrants was widespread. From the end of World War II to the 1970s, illegal immigration was the de facto migration policy advocated by the French government. Throughout the 1950s and 1960s, the ONI had the official monopoly on the introduction of foreign labor into France. In reality, however, direct hire of foreigners by employers and subsequent regularizations of status were the norm. This arrangement between employers and the state has its legal basis in a circular issued by the Ministry of Labor on April 18, 1956, which put "regular" immigration organized by ONI and post-arrival regularization procedures on the same plane, and encouraged regularization of workers in sectors where there were labor shortages (Spire 2005).

This leniency in the introduction of foreign labor was related to an economic recovery in 1955-1956 and the start of the war in Algeria, which drained native manpower from France and limited the ability of employers to recruit labor from North Africa. In the decade following the issuance of this circular, the vast majority of foreign workers in France underwent regularization after irregular arrival and irregular employment. Laubenthal (2007) reports that $80 \%$ of foreign workers in France at the end of the 1960s underwent this adjustment of status, and that the ONI's role was effectively reduced to conducting post-arrival regularizations. Economic conditions-growth and the demand for flexible labor-thus created political tolerance of irregular migration, and the legal framework was adapted to allow these employers to hire and adjust the status of these flexible workers. Furthermore, most of the beneficiaries of this ongoing regularization regime were Portuguese, Spanish, or Italian, and Spire (2005) argues that this legal mechanism was motivated, in part, by a desire to counterbalance the ability of racially distinct former colonial subjects from Africa to enter and work in France without the need for official authorization.

An economic slowdown in 1965 pushed French authorities to reconsider this "spontaneous" immigration system that escaped the boundaries of formal immigration law. Post-arrival regularizations, which had been the lifeblood of French labor recruitment, were scaled back by a circular issued on July 29, 1968 by the Ministry of Social Affairs. While in legal terms this circular only called for a stricter application of the laws already on the books (which did not allow for post-arrival 
regularizations), in practical terms it did start to impede regularizations, the rate of which dropped from 82\% in 1968 to $60.3 \%$ in 1971 (CERC-Association 1999). The fact that this measure did not completely prevent regularization was due to the fact that it continued to allow Portuguese nationals and workers in certain sectors (including domestic workers) to be regularized. It is reasonable to assume that many Senegalese migrants experienced spells of irregularity during this period given the tolerance and even encouragement of unauthorized entry by both the state and employers.

\section{The End of Regularization and the Suspension of Labor Immigration}

Further slowing of the economy and an increasing desire on the part of French authorities to control "irregular" migration-which was, in reality, produced by the administrative interpretation of the 1945 ordonnance-prompted additional restrictions on post-arrival regularizations in 1972. The Marcellin and Fontanet circulars, issued by the Ministries of Interior and Work, respectively, effectively limited regularizations by requiring employers requesting the regularization of a foreign employee to post an offer for the foreigner's job with the Agence national pour l'emploi (ANPE), allowing French nationals to apply for it (Spire 2005). These measures seem to have had their intended effect, as the regularization rate dropped below $60 \%$ in 1972 and 1973, although Portuguese were still exempt from these restrictions.

The 1972 circulars also undertook a major reform in the system of residence and work permits, which both reduced the ability of foreign workers to regularize their status after arrival and created new kinds of irregularity. The circulars envisaged a "guichet unique" where migrant workers would apply simultaneously for residence and work permits. These permits were to be issued for the same length of time, eliminating the possibility that migrants could have regular status in one legal domain and not the other. The circulars also subjected the issuance of a residence permit to the possession of a work permit: a foreigner applying for these authorizations filled out a single form and had to produce a work contract and a certificate of an offer of employment endorsed by the ANPE (Spire 2005). Workers without a formal work contract were unable to obtain authorization to work or reside in France and were ineligible for exceptional regularization procedures; these circulars, in attempting to create a system of stricter immigration control, thus transformed formerly regularizable workers into irregular migrants (Spire 2005).

\subsubsection{The 1970s: The "Closing" of the French Border and the Erosion of the Bilateral Accord}

Major changes to French immigration policy wrought by the economic crises in the 1970s would further erode the special status of Senegalese migrants in France granted by the independence-era bilateral accords. After almost three decades of 
economic growth and relative prosperity, the oil shock of 1973 sent the world and French economies into a tailspin. Even before this climactic event, unemployment had been increasing and there was growing restlessness about the increasing number of foreign workers in France and the relative ease with which they entered the country and subsequently found jobs and regularized their situations (Laubenthal 2007).

In addition, France saw an increasing influx of foreigners from its former colonies in North and West Africa, including Senegal. The economic situation in Senegal declined starting in the 1960s. A major drought started in 1969 while the world market for peanuts collapsed after the end of French price support; and the 1973 oil crisis combined with high population growth to reduce Senegal's economic prospects (Mezger Kveder 2012). Unlike the Spanish, Portuguese, and Italian immigrants of the early post-war period who were seen as having similar cultural values and were thus prized not only for labor purposes but also for demographic "repeopling," former colonial subjects such as those from Senegal were perceived as difficult to assimilate into the French polity and way of life (Spire 2005).

The French government responded to these economic and social pressures by unilaterally suspending labor immigration through a decision by the Council of Ministers on July 3, 1974. Administrative circulars "temporarily" put an end to the introduction of salaried workers on July 5 and to the introduction of applications for family reunification on July 9 of that year. The circulars officially activated the government's ability to refuse applications for cartes de séjour based on the national employment situation (CERC-Association 1999). The suspension of family reunification provisions, formalized in a decree issued on September 27, 1974, was rejected by the Conseil d'Etat and reunification procedures, under stricter lodging conditions, were officially reinstated by the government on April 29, 1976 (CERCAssociation 1999).

While the circulars contained exemptions to allow for the entry of foreign labor in sectors where the national labor supply was insufficient (Gokalp 1975), the "temporary" suspension of labor immigration became de facto permanent over the course of the 1970s, with recourse to rejections of applications for residence and work permits because of the national employment situation increasingly common (CERCAssociation 1999). Contemporaneous study of the impact of these measures indicated that they had been successful in reducing entries, but also in increasing the irregularly resident population (Gokalp 1975).

In addition, in an effort to prevent immigrant workers from entering and working in France, all categories of foreigners wishing to enter the country-students, refugees, reunified family members-faced suspicion of being "hidden workers" and thus underwent additional scrutiny from enhanced immigration-control systems (CERC-Association 1999). These administrative actions also actively created irregularity of status by denying residence and work authorizations, and the French state thus had to identify and deal with these irregular migrants by trying to repatriate or regularize them. 


\section{Establishment of the Carte de Séjour Requirements for Senegalese}

The decision to suspend labor immigration further eroded the bilateral regime that defined the legal framework of Senegalese migration to France. The stricter control on migrant labor enacted in the 1972 and 1974 circulars reflected an increasing emphasis on border surveillance and the control of labor flows, which had long been marginalized by postwar immigration policy's de facto tolerance of irregular immigration and post hoc regularization (Spire 2005). The ability of Senegalese and other sub-Saharan Africans formerly under colonial control to enter and reside in France without authorization clashed with this new emphasis on the "maittrise des flux" (immigration control) and so the Ministry of the Interior finally convinced the Ministry of Foreign Affairs to re-negotiate the treaties that created this preferential regime (Spire 2005). Senegal and France signed a re-negotiated bilateral accord on March 28, 1974 that required Senegalese staying in France for more than 3 months to "possess and produce upon demand" a titre de séjour (residence authorization) but did not require a visa for entering the country. Senegalese living in France as of January 1, 1974 were issued a renewable residence permit that would be valid for not less than 5 years.

While this bilateral accord was not ratified until December 19, 1975, the French Ministries of Labor and the Interior issued circulars on November 30, 1974 requiring all nationals of sub-Saharan African states formerly under French administration to be in possession of a titre de séjour from January 1, 1975 onwards. Senegalese and some other African nationals were not required to apply for a separate carte de travail, but the circulars specified that the issuance of the titre de séjour was contingent upon presentation of a government-approved work contract issued prior to the departure from the origin country. Family reunification was still allowed, but was conditional on a certificate of lodging and a medical exam of the family members (Gokalp 1975; Marot 1995; Viet 1998).

While the Interior and Labor circulars of 1974 respected some of the elements of the Franco-Senegalese treaty of 1974 (such as the issuance of a 5-year residence permit for Senegalese already residing in France, as opposed to a 3-year permit issued to other African nationals), they went beyond the scope of the accord by making a residence permit contingent on a work contract. The Conseil d'Etat canceled some of the measures in 1978, including the ability to reject applications based on the national employment situation (thus partially reaffirming the special status of former colonial subjects), but it reaffirmed the general principles that Senegalese and other former colonial subjects were required to have a titre de séjour and that this permit could be conditioned on having a formal work contract certified by the Ministry of Labor (Marot 1995).

The renegotiation of the bilateral accord and subsequent unilateral abrogation of the bilateral treaties previously on the books in 1974 thus moved the "preferential regime" for Senegalese much closer in line with the general regime. With labor immigration officially suspended, the work contract on which successful applications 
for a residence permit depended would be almost impossible to acquire, thus effectively limiting the ability of Senegalese to enter France for work. This requirement probably had only a small impact on the official flow of Senegalese workers to France, however, as their numbers were already limited by the difficulty, even prior to 1974, of acquiring a work contract (Bergues 1973).

The main impact of requiring a residence permit and making it conditional on a work contract would make it almost legally impossible for Senegalese who entered France as "tourists" to stay for more than 90 days. These modifications of the bilateral regime thus created new possibilities for irregular status for Senegalese migrants: those entering legally as "tourists" would become irregular by staying past 90 days, and those Senegalese already in France as of 1974 would inevitably become irregular after the expiration of their first residence permit if unable to present a formal work contract to accompany their application for renewal.

It is no coincidence that these modifications to the preferential regime occurred in 1974, a moment during which there was political and economic momentum for the closing of French borders to foreign workers. These modifications also drew on the innovations introduced by the Marcellin-Fontanet circulars of 1972, especially the concept of the "guichet unique," which created a single residence and work permit and made residence authorization conditional on a formal work contract. At the same time, Senegalese and other sub-Saharan Africans were required to interact with the French administration via an "office of foreigners with special status," often staffed by former colonial administrators with "expertise" in dealing with subSaharan Africans, thus indicating that the integration of these former subjects into the general regime was not yet complete (Spire 2005).

The rest of the 1970s saw the general immigration-control regime drift further towards policies of exclusion and surveillance. While the 1974 circulars had been effective at reducing immigration to France, they did not eliminate it completely, and those migrants that remained became more focused on settlement in France as the borders closed (Schain 2008). The French government thus decided in 1977 to suspend family reunification (reversed the following year by a decision of the Conseil d'Etat) and initiated policies to facilitate the "voluntary return" of migrants (Schain 2008).

Senegalese migration to France evolved as a result of these changes to French immigration policy in the 1970s. Restrictions on labor immigration encouraged settlement among formerly mobile Senegalese, and leading some single male migrants to bring wives and children via family reunification (although Beauchemin et al. 2013 suggest that Senegalese have been quite reluctant to reunify in Europe). Qualitative studies have also found visa overstaying among Senegalese to be prevalent since 1974 (Tall 2008). 


\subsubsection{The 1980s: Immigration Policy as a Political Football and Consensus in Border Security}

The alternation between right- and left-wing governments in the 1980s led immigration policy to experience multiple swings between restriction and liberalization but led to a convergence on the issue of border control that would eventually serve as the foundation for a complete abrogation of the special regime of the bilateral accords. The decade saw, for the first time, major revisions of the 1945 ordonnance governing the general immigration regime. The decade began with a re-entrenching of the exclusionary policies enacted in the 1974 circulars via the Bonnet law. Passed by a right-wing government in 1980, the law tightened entry requirements by requiring repatriation guarantees and declared the entry or residence of "illegal" migrants to be a threat to public order (Schain 2008). The law also made expulsions of undocumented migrants easier, even if they were minors or had family attachments (Schain 2008).

Further measures in the early 1980s targeted migrants resident in France as a threat to public order and laid the legal basis for their expulsion. The Peyrefitte law of 1981 increased the policing power of the state vis-à-vis migrants by allowing preventative identity checks of suspected undocumented migrants. A circular from the Ministry of Labor on June 10, 1980 encouraged the labor administration to invoke the national employment situation as a motive for refusing the renewal of work permits, which would make migrants ineligible for renewal of their residence permits; this motivation for refusal was even applied to those migrants who were still employed, effectively expelling them from France (CERC-Association 1999). Deportation became a primary tool of the French government for both combatting "clandestine" immigration and employment and making migrants' stays in France precarious (Miller 1994). As Senegalese were subject to requirements for residence permits conditional upon work authorization from 1974 onward, these restrictive measures undoubtedly affected them as well.

The arrival of the left-wing Mitterrand government to power in 1981 inaugurated an era during which immigration policy was a political football for alternating leftand right-wing governments. Between August and October 1981, a series of reforms sought to roll back some of the restrictive measures of previous years: incentives to return were abolished; the government eliminated the provisions of the Bonnet law allowing the expulsion of minors and parents of French children or children born or arrived in France before the age of 10; and a vast regularization program adjusted the statuses of 132,000 migrants (CERC-Association 1999). The Dufoix law of July 17, 1984 followed these liberalizing reforms with a complete revision of the system of residence permits, reducing their number to two.

The Dufoix law introduced a 10-year carte de résident, which granted work authorization and was automatically renewable; this permit thus removed the obligation of 
prior work authorization for settled immigrants and implicitly recognized the permanent nature of immigration to France (Weil 1995). The law also defined a temporary carte de séjour with a maximum validity of 1 year. Foreigners wishing to work would still need a prior work authorization, but a foreigner not wishing to work in France could be authorized to stay without working upon proof of adequate means of existence (CERC-Association 1999). The guichet unique of the 1972 Marcellin-Fontanet circulars was thus enshrined in legislation, abolishing the duality of residence and work permits while making the former dependent on the latter.

Despite these reforms, some of the previous government's restrictive measures were maintained, including preventative identity checks and the retention and forced expulsion of some migrants (CERC-Association 1999). Additional restrictive reforms were initiated under the right-wing "cohabitation" government led by Prime Minister Chirac from 1986 to 1988. The first Pasqua law of 1986 facilitated expulsion procedures and restricted access to 10-year permits (Schain 2008). The resumption of a left-wing parliamentary majority in 1988 led to the Joxe law of 1989 that eased some of the restrictive measures of Pasqua's law.

Regardless of the political and legislative jousting over immigration, there was an increasing convergence between the left and right on issues of border security: while opposed on issues of immigrant integration and security of residence, both sides seemed to find political utility in securing the frontier through increased external controls, rejection of asylum claims, and increased police control and occasional roundups of suspected undocumented immigrants (Schain 2008).

\subsubsection{Visa Requirements for Senegalese and the Re-negotiated Bilateral Accord of 1995}

\section{Unilateral Imposition of Visa Requirements in 1986}

The evolution across the political spectrum towards a system of hardline external controls led to fundamental changes to the bilateral immigration regime with Senegal. Against a backdrop of terrorist attacks in Paris, the French government unilaterally suspended, via a notice from the Ministry of Foreign Affairs on September 16, 1986, the clauses of bilateral treaties exempting Senegalese and other sub-Saharan Africans from visas for entry to France (Marot 1995). While this measure initially applied to Americans, Canadians, and EU nationals as well as nationals of former French colonies, the French government would subsequently exempt citizens of developed countries, thus creating a system of external controls for developing countries deemed to present a "migratory risk." This measure added external control to the Senegalese immigration-control system. Following the requirements that Senegalese possess residence and work permits in 1974, the 1986 abrogation of the treaty and requirement of visas moved the Senegalese immigration regime yet another step closer to integration with the general regime. 


\section{New Bilateral Accord}

The abrogation of the independence-era accord in 1986 and the establishment of entry visas for Senegalese opened the door to further alignment of the bilateral system with the general regime. While the Franco-Senegalese treaty of 1974 instituted requirements for residence permits, the unilateral imposition of visa requirements by the French government in 1986 was at odds with the existing accord. A new treaty was thus signed by France and Senegal on August 1, 1995 ${ }^{1}$ that codified the visa requirements of 1986. Senegalese wishing to enter France for a stay of less than 3 months had to apply for a visa and show both proof of means of existence during the stay and a return-trip ticket to Senegal. For stays longer than 3 months, Senegalese had to apply for a long séjour (long-stay) visa. If they wished to work upon arrival, the treaty required them to have an approved work contract prior to departure in addition to a long-stay visa.

This new system of visas for Senegalese mirrored the visa requirements of the Schengen system. An inter-ministerial committee decided on July 10, 1991 to promulgate as official policy the "control of migratory flows" (maîtrise des flux migratoires) in keeping with France's 1990 accession to the Schengen treaty and its stringent border-control requirements. These developments led to a new push to revise the bilateral treaties with African states. The Senegalese treaty required a residence permit for all stays in France exceeding 3 months. While the exact regulations governing granting of this permit were not specified, it is likely that they were subject to the prevailing legislation regarding residence permits (i.e., that they were conditioned on having a formal work contract or proof of means of existence). The only nod to the formerly privileged status of Senegalese was the provision for granting a 10-year titre de séjour after continued regular residence of 3 years as opposed to 5 years in the prevailing legislation; Senegalese were otherwise subject to provisions in line with the general immigration regime.

\subsubsection{The 1990s: Pasqua, Debré, and the Sans-Papiers Movement}

The 1990s brought both increased emigration pressure to Senegal and further alignment of the Senegalese immigration framework with general French policies. Senegal agreed to implement a series of structural adjustment programs (SAPs) in the 1980s and 1990s, which aggravated urban poverty and produced unsatisfactory macroeconomic outcomes (Mezger Kveder 2012). The Senegalese currency, the CFA franc, was devalued in 1994. Although this move restored some competitiveness to the Senegalese economy and improved monetary measures of poverty, survey results suggest that the majority of Senegalese perceived their economic

\footnotetext{
${ }^{1}$ Although signed in 1995, the treaty was not published in the Journal officiel de la République Française until March 12, 2002.
} 
well-being to have stagnated or deteriorated in the late 1990s (Mezger Kveder 2012). During this mostly negative economic evolution, Senegal became a net exporter of migrants.

French immigration policy in the 1990s further increased restrictions on Senegalese and other sub-Saharan African migrants via the Pasqua and Debré laws. The right-wing cohabitation government headed by Balladur in 1993 overtly proclaimed a goal of "immigration zéro" (Hollifield 1999), which was translated into legislation by the second Pasqua law. The goal of this law was to roll back procedural and social rights for immigrants in France and limit their ability to settle in the country (Hollifield 1999).

The law also created new forms of legal precarity for a number of categories of migrants: it made acquisition of French citizenship more difficult for children born in France, facilitated the expulsion of undocumented foreigners, increased waiting time to 2 years for family reunification, prohibited the regularization of undocumented migrants who married a French citizen, made the issuance of residence permits dependent on the regularity of entry and prior stay, and denied re-entry for 1 year for expelled foreigners (Hollifield 1999; Schain 2008; Wihtol de Wenden 2002). This law, in pursuing a zero-tolerance strategy on immigration, thus created new pathways into irregularity by making it more difficult to gain and maintain regular status.

The Pasqua law also created contradictory legal situations for many migrants in which they were "ni régularisable ni expulsable" (neither regularizable nor deportable). Such migrants were not eligible for renewal of status because of the restrictions in the Pasqua law, but also could not legally be deported, often because of other provisions in existing laws that protected migrants who had resided in France for a long time or those with "attachments" in France from being deported (Hollifield 1999). Of particular consequence for Senegalese and other African migrants were restrictions on accessing and renewing residence permits for polygamous families, which forced "secondary" spouses to choose either divorce and "décohabitation," remaining in a polygamous union and falling into irregular status, or returning to Africa (Alaux 2001).

Choosing to remain in a polygamous marriage would mean falling into the gray zone of being neither regularizable nor deportable for both secondary spouses and their husbands: they would not be eligible for renewal of residence permits, but they could not be deported since most had minor children who qualified their parents for protection. While not all Senegalese families were polygamous, the law certainly drew on public anxieties about African polygamy to restrict this family form, echoing the debate from the colonial administration in Senegal that saw polygamy as incompatible with French citizenship.

The contradictions inherent in the Pasqua law gave rise to the sans-papiers movement of 1996. This movement was made up of Senegalese and other West Africans, many of whom were neither regularizable nor deportable because of the Pasqua law. More than 300 migrants camped in two different churches in Paris between March and August 1996 to bring public attention to their legal plight (Marin 2006). They demanded that the government recognize the absurdity of their 
administrative situations and offer pathways to regular status. The occupation of the Saint-Bernard church ended dramatically with the French National Police in riot gear chopping down the wooden door and forcibly evacuating the sans-papiers, but not before garnering national attention that spurred 10,000 people to march in Paris in support of their cause in February 1997 (Marin 2006; Terray 2006).

The government, led by then-President Chirac, responded in April 1997 with another modification of the 1945 ordonnance. The Debré law, although it sought to resolve some of the "ni...ni" contradictions of the Pasqua law highlighted by the sans-papiers movement, actually contained provisions that would make it "impossible for most of the protesters to regularize their status" (Schain 2008: 54). While French-born minor children of irregular migrants and foreign spouses of French citizens with irregular status could neither receive an adjustment of status under the Pasqua law nor be deported because of their family attachments, the Debré law set the bar unrealistically high for regularization of these categories of migrants. "Foreign" children under the age of 16 would have to demonstrate 10 years of continuous residence in France before being granted a 1-year residence permit, and "foreign" spouses had to have been married for 2 years before being eligible for the same 1-year permit (Hollifield 1999; Schain 2008). The law thus prolonged the duration of irregularity for these "ni...ni" migrants with strong family links to France. The Debré law also increased the state's surveillance power of suspected irregular migrants: it allowed the confiscation of the passports of migrants in an irregular situation, the storage of fingerprints of foreigners applying for a residence permit, increased police power, and restricted judicial power in matters of retention of irregular migrants (Hollifield 1999).

Hollifield argues that one of the underlying intents of the Pasqua and Debré laws was to "devise a system for controlling entries by Africans" (1999: 83). The Pasqua law's targeting of polygamous families was clearly aimed at African migrants, and its hardening of the barriers to legal stay and acquisition of citizenship for children of irregular migrants demonstrated a desire to uproot entire families. Early versions of the Debré law required French citizens to report the presence of any foreigners hosted in their domicile, with a number of countries exempted except for those in Africa (Schain 2008). While these provisions were softened in the final version of the law, the intent was clearly to make it more difficult for Africans to reside in France. This system allowed the French government to control African immigration without resorting to American-style numerical quotas, which would have clashed with republican ideals of egalitarianism in visa requirements for citizens of developing countries and also would have been seen as discriminatory towards former colonies (Hollifield 1999).

The election of a socialist majority to the Assembly in 1997 led to another period of political cohabitation, this time with the right maintaining control of the presidency and the left gaining control of the office of Prime Minister. The Jospin government gave a high priority to immigration reform, promising to resolve the ambiguities of status created by the legal labyrinths of the Pasqua-Debré laws and re-establishing the republican foundations of immigration. The Interior Minister issued a circular on June 24, 1997 instructing préfets to proceed with case-by-case 
regularizations with provisions for the adjustment of status of spouses with irregular status and children of migrants with irregular status (Levinson 2005a).

A direct result of the sans-papiers movement and its widespread public support, this regularization program attracted 150,000 applications and eventually adjusted the status of 90,000 people, $85 \%$ of whom were regularized for family reasons (Levinson 2005a; Terray 2006). These regularizations, however, only allowed the granting of temporary, 1-year permits, thus prolonging the precarity of many groups of migrants and imposing the paradoxical burden of having to document their previous irregular status in order to gain access to more permanent residence permits (GISTI 2011).

While the 1997 regularization program sought to quickly resolve some of the contradictions of the Pasqua-Debré laws, the Jospin government also passed legislation to alter those laws. Drawing on the recommendations from a committee headed by Patrick Weil, a French historian of immigration, the 1998 Chevènement law (also known as the RESEDA law) included broad changes in the system of issuing residence permits designed to reinforce the rights of migrant families in France: minors brought to France for family reunification, foreigners who entered France before the age of 10, foreign parents of French children, and foreign spouses of French nationals would all receive initial 1-year residence permits (Hollifield 1999). The law also included a provision granting a residence permit to any foreigner able to prove residence in France for 10 years (Hollifield 1999). This provision gave rise to ongoing régularisations au fil de l'eau ("on-the-fly regularizations") during the following decade in which migrants from sub-Saharan Africa are over-represented (Lessault and Beauchemin 2009). The Jospin government also reformed the nationality code with the Guigou law of 1998, which reinstated limited jus soli provisions: individuals born in France could obtain French nationality at the age of 18 if they had lived in France for at least 5 years after age 11, or parents could request naturalization for minors as early as age 13 if the child had lived continuously in France for 5 years (i.e., since age 8) (Hollifield 1999).

Despite these changes and the assertions of the Jospin government that immigration was in keeping with the French republican tradition, the 1997-1998 laws continued many of the restrictive policies of the 1980s, including tightened visa requirements and provisions for detention and expulsion of irregular migrants (Schain 2008). Indeed, Schain (2008) argues that the trend in immigration policy in France has been towards a commitment to certain forms of control regardless of which political party holds office. This commitment has mostly been towards exclusion of immigrants, with right-wing governments tending towards tightening existing requirements; left-wing governments, on the other hand, have not attempted to roll back exclusionary restrictions but have merely increased judicial oversight (Schain 2008).

By 1997, then, the former preferential regime allowing free circulation of Senegalese had been completely dismantled by successive re-negotiations of treaties, and the general immigration-control system was modified in such a way as to limit entries of Senegalese and to make it difficult for them to stay and work legally in France. Thus the trend of the immigration-control system vis-à-vis Senegalese 
towards restriction has paralleled a similar movement in the overall regime. Some research points to the decline of the immigration of demographically valuable southern European migrants and the increase in racially and religiously distinct immigration from the former colonies as a main driver of this exclusionary impulse (Hollifield 1999); thus the evolution of restrictions on African migration to France cannot be separated from the exclusionary trend in the general immigration-control regime.

\subsubsection{The 2000s: Selective Immigration and Coordinated Migration Management}

Reorientation of French policy towards further restriction and selective immigration in the early 2000s gave rise to a new round of bilateral accords with Senegal and other countries that aimed at cooperative management of "unwanted" immigration flows in exchange for the opening of pathways to "wanted" immigration flows. Interior Minister Sarkozy pushed for a 2003 law in the wake of Chirac's 2002 faceoff with Jean-Marie Le Pen that toughened the provisions of the 1998 Chevènement legislation by easing the expulsion process and increasing the period of detention for irregular migrants to 32 days (Schain 2008). In addition, it reinstated some provisions of the Pasqua-Debré laws that the Chevènement law had abolished, such as the granting mayors the power to refuse entry to foreigners and strict controls on marriage with a foreign spouse. It also increased the waiting time for a permanent residence permit, and made the issuance of permanent and family-reunification permits contingent on proof of "good integration" (Schain 2008). As the 1945 ordonnance regulating immigration to France had seen 23 revisions (including 11 since the mid-1990s), the French government decided to consolidate the post-war measure into the "Code de l'entrée et du séjour des étrangers et du droit d'asile" (CESEDA) in 2005.

A second Sarkozy law was passed by the right in 2006 that reinforced some of the restrictive measures of the 2003 law while opening France to new kinds of immigration. The law allowed for some kinds of immigration choisie (selective immigration), mainly higher-skilled workers. This was paired with further restrictions on immigration subie (uncontrolled or non-selective immigration), including the requirement of the agreement to a contrat d'accueil et d'intégration (welcome and integration contract) for the issuance of family-reunification permits or permanent residence permits and the repeal of the provision for regularization of longterm residents and.

The push for selective immigration undergirded a new round "accords relatifs à la gestion concertée des flux migratoires et au codéveloppement" ("accords relating to the joint management of migratory flows and to codevelopment"), which ostensibly aimed to include developing countries such as Senegal in the coordinated management of migration flows. The French government founded these accords on the 
organization of some kinds of legal immigration, the fight against illegal immigration, and increased co-development efforts (see Kabbanji 2013 for an analysis of co-development programs). Senegal and France signed such a treaty on September 23, 2006 and it came into force on September 1, 2009. The treaty included provisions for issuance of residence permits that would permit a salaried activity to Senegalese with a job offer in any of ten listed professions (La Cimade 2009). While some of these professions, such as those in information technology, banking, and medicine, demanded high levels of skill and training, the list contained other, lessskilled professions in industry, agriculture, construction and building trades, and services (security, hairstyling, etc.).

In addition, the accord indicated that these residence permits were available to all Senegalese with a job offer in these professions, including those irregularly resident in France (La Cimade 2009). The treaty included provisions for Senegalese students in France and allowed for special categories of visas for business people, academics, scientists, artists, and athletes. As a counterweight to these measures to facilitate legal immigration, the treaty introduced new mechanisms for fighting illegal immigration. It included a readmission clause, whereby Senegal agreed to facilitate the return of Senegalese nationals found to be residing irregularly in France. The treaty also promised $€ 2.5$ million in funds for development projects and measures to encourage Senegalese migrants in France to invest their savings in businesses in Senegal (La Cimade 2009).

This new generation of treaties has come under fire for multiple reasons. Many of the measures for promoting legal immigration were already part of the CESEDA (such as the availability of visas for artists, scholars, athletes and other highly skilled professionals and a basic list of professions which were open to foreigners) (La Cimade 2009). Of more concern was the linking of increased control of irregular migration with development aid: it seemed that France was exchanging relatively meager sums and vague promises of co-development for readmission agreements that, in many ways, violated human rights (La Cimade 2009). Selective immigration as conceived under the 2006 Sarkozy law thus seemed to serve as rhetorical device for severely controlling migration from Africa while the bilateral accords paid lip service to the "special relationship" between France and her former colonial possessions.

\subsection{Senegalese Migration to New Destinations in Southern Europe}

The closing of the French border in the 1970s, high French unemployment, and the restructuring of French industries in the 1980s conspired with long-term economic decline in Senegal to lead Senegalese migrants to seek out new destinations in Southern Europe (Riccio 2008; Schoumaker et al. 2013). Senegalese migrants also responded to the demand for inexpensive and flexible workers in the secondary and 
informal labor markets as well as the relative ease of residential integration into Italy and Spain (Fall 2005; Pascual de Sans et al. 2000). These new destinations also attracted migrants from different social origins than earlier waves of labor migrants to France. Instead of originating in the rural Senegal River valley, migrants to Italy and Spain have tended to come from the predominantly Wolof zones of western Senegal and its urban areas (Schoumaker et al. 2013). In addition, the social networks that amplified this movement were embedded in religious affiliations, with the Senegalese Mouride Islamic brotherhood providing spiritual motivation and material support to its adherents in the new destinations (Babou 2002; Ebin 1992). Figure 2.1 shows the increasing importance of these new destinations: while stocks of Senegalese in France remain higher than those in Southern Europe, the number of Senegalese resident in Italy and Spain has grown dramatically since the 1990s (Mezger Kveder 2012).

Migration flows in general to Italy and Spain were rare prior to the 1970s, and neither country had effective immigration policies before the mid-1980s (Laubenthal 2007; Pascual de Sans et al. 2000). The accumulation of a large stock of illegal immigrants prior to these policies also necessitated a series of legalization programs, and each country has embarked on six regularization efforts since 1985 (Kraler 2009). There is some speculation that regularization programs in both countries actually attracted the first Senegalese migrants to these new destinations (Fall 2005; Kaag 2008; Tall 2008). These programs have undoubtedly had an impact on Senegalese migrants and migration patterns: a full $55 \%$ of all foreigners legalized in

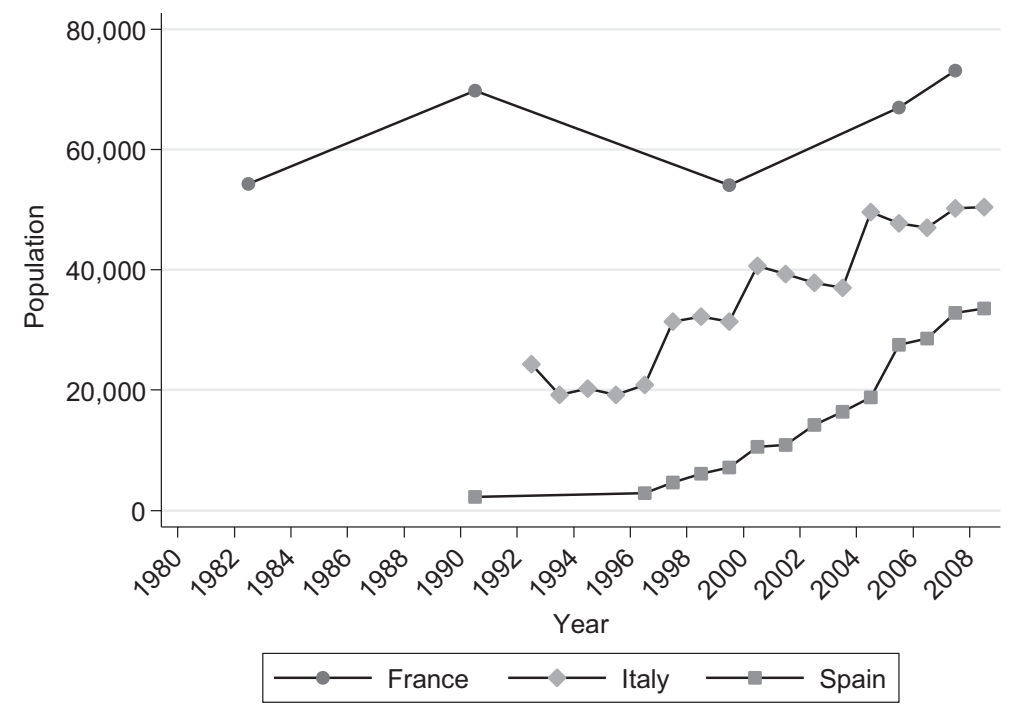

Fig. 2.1 Senegalese migrant stocks in France, Italy, and Spain (country of birth). Reproduced from Mezger Kveder (2012). Sources: United Nations Global Migration Database (UNGMD): France 1982, 1990; Spain 1990; Institut National de la Statistique et des Etudes Economiques: France 1999, 2005, 2007; Istat: Italy 1992-2008; Ministerio de Trabajo e Inmigración a partir de datos suministrados por Ministerio del Interior: Spain 1996-2008 
Spain's 1991-1992 program were from Africa (Pascual de Sans et al. 2000), and Senegalese are among the most numerous participants in Italy's regularization programs (de Haas 2008). ${ }^{2}$ Despite granting legal status, many of these regularization programs required renewal every few years, often leaving Senegalese migrants' legal status precarious and temporary.

The next two sections trace the development of immigration policies in Italy and Spain.

\subsection{Italy}

\subsubsection{Pre-1986: Italian Emigration and the Fragmentation of Immigration Policy}

The history of Italy's immigration-control policies is much more recent than France's and lacks almost all of France's bilateral relationship with Senegal. Most accounts of Italy's immigration policy emphasize that the country was, up until the 1970s, a net sender of migrants and thus had little practical need for a wellestablished system to control immigration (Sciortino 1999). Fascist-era laws between 1929 and 1931 dealt mostly with political immigration as a public-security issue and subsequent measures were fragmentary and mainly in the form of administrative circulars (Mezger and González-Ferrer 2013; Sciortino 1999).

\section{Mechanisms of Internal Control}

Despite this fragmentation, a law in 1961 (Legge 1961-5) repealing restrictions on internal migration allowed for the introduction of foreign labor through employer application to a local employment office (see Table 2.3 at the end of Sect. 2.4 for a synthesis of the evolution of immigration policy in Italy). If native workers were not available, the employment office was to issue a labor permit (autorzzazione al lavoro) and the foreigner could apply for a visa to enter Italy. The worker was issued a permesso di soggiorno per motivi di lavoro that was linked to a specific contract, meaning that residence authorization would end with the expiration of the contract (Sciortino 1999). This early law adumbrated some of the features of future Italian immigration-control policy, including the state brokerage of labor migration and the conditioning of residence permits on work authorizations and formal contracts.

Labor migration to Italy nonetheless remained limited through the 1980s, and most internal controls consisted of police checks for the "morality" and public order of immigrants (Sciortino 1999). Another law in 1981 was motivated by the

\footnotetext{
${ }^{2}$ Sub-Saharan Africans were also overrepresented in France's recent regularization programs (Lessault and Beauchemin 2009).
} 
Table 2.3 Synthesis of major immigration measures in Italy and consequences for migrant irregularity

\begin{tabular}{|c|c|c|}
\hline Date & Name of law & Consequence for irregularity \\
\hline $\begin{array}{l}\text { February } \\
10,1961\end{array}$ & $\begin{array}{l}\text { Legge 1961-5: Abrogazione della legislazione } \\
\text { sulle migrazioni interne e contro l'urbanesimo } \\
\text { nonchè disposizioni per agevolare la mobilità } \\
\text { territoriale dei lavoratori }\end{array}$ & $\begin{array}{l}\text { Allowed for the introduction } \\
\text { of foreign labor through } \\
\text { employer application to a } \\
\text { local employment office }\end{array}$ \\
\hline \multirow[t]{2}{*}{$\begin{array}{l}\text { September } \\
17,1966\end{array}$} & \multirow[t]{2}{*}{ Circolare n. 38, Ministero degli Affari Esteri } & $\begin{array}{l}\text { Exempted Senegalese citizens } \\
\text { from visa requirements for } \\
\text { entering Italy }\end{array}$ \\
\hline & & $\begin{array}{l}\text { Required Senegalese to } \\
\text { "regularize their position" if } \\
\text { they intended to "settle" }\end{array}$ \\
\hline $\begin{array}{l}\text { April 10, } \\
1981\end{array}$ & $\begin{array}{l}\text { Legge 1981-158: Ratifica ed esecuzione delle } \\
\text { convenzioni numeri 92, } 133 \text { e } 143 \\
\text { dell'Organizzazione internazionale del lavoro }\end{array}$ & $\begin{array}{l}\text { Ratified ILO convention on } \\
\text { rights of migrant workers }\end{array}$ \\
\hline $\begin{array}{l}\text { March 2, } \\
1982\end{array}$ & $\begin{array}{l}\text { Circolare del Ministero del lavoro n. 14194/IR/A: } \\
\text { Accesso all'impiego di lavoratori extracomunitari }\end{array}$ & $\begin{array}{l}\text { Froze issuance of work } \\
\text { permits for foreigners }\end{array}$ \\
\hline $\begin{array}{l}\text { December } \\
30,1986\end{array}$ & $\begin{array}{l}\text { Legge 1986-943: Norme in materia di } \\
\text { collocamento e di trattamento dei lavoratori } \\
\text { extracomunitari immigrati e contro le } \\
\text { immigrazioni clandestine }\end{array}$ & $\begin{array}{l}\text { Created framework for } \\
\text { introduction of foreign labor }\end{array}$ \\
\hline \multirow[t]{5}{*}{$\begin{array}{l}\text { February } \\
28,1990\end{array}$} & \multirow[t]{5}{*}{ Legge Martelli 1990-39 } & $\begin{array}{l}\text { Introduced visa requirements } \\
\text { for Senegal and other } \\
\text { countries }\end{array}$ \\
\hline & & $\begin{array}{l}\text { Allowed expulsion for the } \\
\text { management of irregular } \\
\text { migration }\end{array}$ \\
\hline & & $\begin{array}{l}\text { Continued recruitment of } \\
\text { labor with yearly quota decree }\end{array}$ \\
\hline & & $\begin{array}{l}\text { Required foreigners to apply } \\
\text { for residence permit within } \\
8 \text { days of arrival }\end{array}$ \\
\hline & & Regularization program \\
\hline \multirow[t]{2}{*}{$\begin{array}{l}\text { November } \\
18,1995\end{array}$} & \multirow{2}{*}{$\begin{array}{l}\text { Decreto-legge Dini 1995-489: Disposizioni urgenti } \\
\text { in materia di politica dell'immigrazione e per la } \\
\text { regolamentazione dell'ingresso e soggiorno nel } \\
\text { territorio nazionale dei cittadini dei Paesi non } \\
\text { appartenenti all'Unione europea }\end{array}$} & $\begin{array}{l}\text { Increased border-control } \\
\text { measures (rejections and } \\
\text { expulsions) }\end{array}$ \\
\hline & & Regularization program \\
\hline \multirow[t]{5}{*}{$\begin{array}{l}\text { July 25, } \\
1998\end{array}$} & \multirow[t]{5}{*}{$\begin{array}{l}\text { Legge Turco-Napolitano 40-1998: Disciplina } \\
\text { dell'immigrazione e norme sulla condizione dello } \\
\text { straniero }\end{array}$} & $\begin{array}{l}\text { Organized the entry of foreign } \\
\text { labor via a yearly quota } \\
\text { decree }\end{array}$ \\
\hline & & $\begin{array}{l}\text { Defined temporary 2-year } \\
\text { residence permits for work }\end{array}$ \\
\hline & & $\begin{array}{l}\text { Created indefinite residence } \\
\text { permit }\end{array}$ \\
\hline & & Regularization program \\
\hline & & Strengthened border control \\
\hline
\end{tabular}


Table 2.3 (continued)

\begin{tabular}{l|l|l}
\hline Date & Name of law & Consequence for irregularity \\
\hline $\begin{array}{l}\text { July 30, } \\
2002\end{array}$ & $\begin{array}{l}\text { Legge Bossi-Fini 2002-189: Modifica alla } \\
\text { normativa in materia di immigrazione e di asilo }\end{array}$ & $\begin{array}{l}\text { Reformed the quota system to } \\
\text { steer entries towards seasonal } \\
\text { work }\end{array}$ \\
& & $\begin{array}{l}\text { Tied length of residence } \\
\text { permit to work permit and } \\
\text { subjected renewal of } \\
\text { residence permit to a formal } \\
\text { work contract }\end{array}$ \\
\hline $\begin{array}{l}\text { Junereased severity of external } \\
\text { controls }\end{array}$ \\
\hline 2011 & Decreto-legge 2011-89 & $\begin{array}{l}\text { Regularization program } \\
\text { gllowed additional } \\
\text { governmental discretion in } \\
\text { case-by-case expulsions of } \\
\text { migrants found to be illegally } \\
\text { residing in Italy }\end{array}$ \\
\hline
\end{tabular}

ratification of the International Labour Organization convention on the rights of migrant workers but did not respond to then-increasing levels of immigration. The Ministry of Labor put a freeze on the issuance of work permits in 1982 in an effort to clamp down on irregular employment, which ultimately led to an increase in such employment (Sciortino 1999).

\section{Mechanisms of External Control}

Italy's system of external control was likewise limited during most of the twentieth century. While visas were technically required for entry to Italy, implementation of this requirement seems to have been "lax" into the 1970s (Sciortino 1999). Senegalese in particular were exempted from the visa requirement beginning in 1966. Following an exchange of diplomatic notes between Italy and Senegal, the Italian Ministry of Foreign Affairs issued a circular on September 17, 1966 exempting Senegalese citizens from visa requirements for entering Italy (Mezger and González-Ferrer 2013). This exemption was motivated by Senegal's previous decision to extend the regime of free circulation with France to all members of the European Common Market, including Italy; the Italian circular was thus reciprocal in nature and dependent on the bilateral relationship between Senegal and France. Despite exempting Senegalese from visa formalities, the circular still required them to "regularize their position" if they intended to "settle" in Italy.

While there is little information on Senegalese in Italy prior to the 1980s, some earlier accounts (Bergues 1973) indicate that Italy may have been a stepping stone in Senegalese migrants' journeys to France, perhaps because of this preferential visa regime. As mentioned above, Senegalese officials in the 1960s were concerned about the effects of emigration given the bilateral regime of free circulation between 
France and Senegal, and thus imposed the requirement of an exit visa for trips to France (Bergues 1973; Kane 2011). The same exit visa was not required for trips to Italy and other countries, so Senegalese occasionally traveled to Italy, which they were able to enter freely, and subsequently entered France under the conditions of the France-Senegal bilateral regime (Bergues 1973).

\subsubsection{6-1998: National-Level Immigration Policy and "Moral Panic"}

Italy passed its first major national-level legislation on immigration in December 1986. The legge 1986-943 outlined the rights of non-European Community foreign workers and formalized the "neo-corporatist" framework (Sciortino 1999) for the introduction of foreign labor that the 1961 law had sketched. A specialized division within the Ministry of Labor was responsible for keeping lists of both job vacancies and non-EU foreigners residing outside of and looking for work in Italy. This division would match foreign workers with vacancies if no native workers were available for the jobs, and provincial labor offices would then issue a work permit (autorizzazione al lavoro) that would allow the foreigner to apply for a visa to enter Italy. While the law does not specify how migrant workers would obtain residence permits, it does specify that work permits were valid for 2 years and that loss of a job prior to the expiration of the work permit was not grounds for revoking the residence permit. Unemployed migrants were encouraged to register on lists of job seekers so that they could be matched with vacancies.

This law, while initially seen as a positive step towards the construction of a rational immigration policy, ultimately created additional pathways into irregular status. The measure allowing unemployed migrants to stay in Italy and register as unemployed was motivated by a desire to give migrant workers more autonomy from employers, but it actually created a pseudo-legal category for migrants working in the shadow economy (Sciortino 1999): in an effort to avoid paying taxes and social insurance, migrants would register as unemployed and continue working informally. The law also contained provisions for the adjustment of status of foreigners with ongoing or past irregular employment with employers willing to regularize them (Reyneri 1998); applications initially had to be submitted within 3 months of the law's passage, but the deadline was extended into 1988 and eventually regularized the status of more than 118,000 people. Nonetheless, many migrants did not qualify for regularization, and new arrivals added to the resident population of migrants with irregular status (Sciortino 1999).

The next Italian law on immigration sought to deal with irregular migration by tightening external controls and security procedures coupled with numerical planning of labor entries. Legge 39 of 1990 (the "Martelli Law"), motivated in part by Italy's recent signing of the Schengen agreement and concomitant desire to reassure other European countries of the integrity of its borders, introduced visa requirements 
for many countries and made expulsion a tool for the management of irregular migration (Finotelli and Sciortino 2009). Indeed, it was at this time that the visa exemption for Senegal and other "immigration-risky countries" was rescinded (Sciortino 1999). In addition, the law continued the neo-corporatist recruitment of foreign labor by defining a yearly decreed quota of legal entries (Finotelli and Sciortino 2009).

In addition to these external controls, the law reformed the system of internal control by defining the conditions for access to the residence permit (permesso di soggiorno). Foreigners staying in Italy for purposes other than tourism needed to apply for a residence permits within 8 days of arrival; the permit, available only to those who entered legally, could last for up to 2 years and was renewable. The law also included a liberal regularization program open to any foreigners residing in Italy before December 31, 1989, which adjusted the statuses of 234,841 migrants (Sciortino 1999). This patchwork of restrictive controls on entries combined with rigid planning tools and a liberal regularization program led to the law's ineffectiveness. With regard to the yearly quota, many employers and foreign workers found the process cumbersome, leading to the informal hiring of irregular migrants (Finotelli and Sciortino 2009).

Growing "moral panic" (Sciortino 1999) over increasing immigration paralyzed further attempts at immigration-policy reform during most of the decade of the 1990s. The government passed an executive decree (the "Dini decree," decretolegge 489) in 1995 that included both harsh border-control measures (expulsions and rejections) to please the populist right-wing Lega Nord (Northern League) and a regularization program to mollify the left (Sciortino 1999). The decree was not enacted within 60 days as mandated by the constitution, so it was re-issued several times over the following year with the same fate (Sciortino 1999). Nonetheless, the government went ahead with the decree's regularization program, which was stricter than the Martelli amnesty: applicants had to prove that they had been residing in Italy, regularly employed during the past 6 months or with an employment offer, and had paid 3 months of social security contributions (Levinson 2005b). Despite these more stringent conditions, the program adjusted the status of 238,000 foreign workers from 1995 to 1996 (Levinson 2005b).

The passage of legge 40 in 1998, also known as the Turco-Napolitano law, put an end to the legislative impasse on immigration policy. Motivated in part by the longawaited accession of Italy to the Schengen zone, this law attempted to offer a comprehensive framework for both management and control measures (Finotelli and Sciortino 2009). The law once again organized the entry of foreign labor via a yearly quota decree. Employers would request a work permit (autorizzazione al lavoro) and entry visa within the quota system, potentially for a specific foreigner who could then apply for the visa abroad. Unlike previous Italian quota systems, though, the Turco-Napolitano law did not require proof of the lack of suitable Italian workers (Reyneri 2004). This requirement had effectively limited legal entries under the quota system to less than 25,000 per year before 1999, making it extremely difficult to enter Italy legally for work (Reyneri 2004). 
In addition to re-establishing the quota system, the law also attempted to promote the integration of migrants by stabilizing their residence situations. Foreigners arriving for work would enter Italy with a visa based on the pre-existing autorizzazione al lavoro and apply for a 2-year permesso di soggiono per lavoro subordinato after arrival. The law defined different lengths for the permesso depending on the motive for the stay: six to 9 months for seasonal work; 1 year for study; and 2 years for self-employment, indefinite-contract employment, and family reunification. Unemployed workers were allowed to keep their residence permits if they registered as unemployed. In addition, the law introduced an indefinite residence permit (carta di soggiorno) accessible after 5 years of legal residence (Finotelli and Sciortino 2009). The implementation of the law also included a regularization program open to unauthorized immigrants present in Italy before March 27, 1998, which ultimately adjusted the status of 193,200 of over 300,000 applicants (Levinson 2005b).

While the Turco-Napolitano law promoted the legal entry, residence, and work of migrants, it also included measures to strengthen border control, make irregular entry more difficult, and facilitate expulsion via readmission agreements (Finotelli and Sciortino 2009). Despite these restrictive measures, the law was unable to deal with the strategy of visa overstaying, which was overtaking clandestine entry as an irregular migration strategy (Finotelli and Sciortino 2009).

\subsubsection{The 2000s: "Strong Restrictive Ambition"}

The Bossi-Fini law of 2002 (legge 189), passed by the second Berlusconi government, was "inspired by a strong restrictive ambition" (Finotelli and Sciortino 2009: 126). The law reformed the quota and internal-control systems so as to limit legal entries. Political discretion in the definition of yearly quotas increased, with the goal of steering legal entries towards temporary, seasonal work. The law subjected residence permits to increased administrative scrutiny through decreased length, and also tied the length of the residence permit to the work permit via the contratto di soggiorno per lavoro (residence contract for work) (Finotelli and Sciortino 2009). This contract, signed by the employer and the employee after recruitment through the quota system, required employers to pay housing and repatriation costs and allowed foreigners to apply for a permesso di soggiorno per motivi di lavoro (residence permit for reasons of work), valid 1 year for fixed-duration contracts and 2 years for unlimited-duration contracts. This law also made renewal of residence permits contingent on having a formal work contract, potentially subjecting many migrants to spells of irregularity (Finotelli and Sciortino 2009).

In addition to limiting legal entries, the Bossi-Fini law sought to combat irregular immigration through the increasing severity of external controls. These included granting powers to the Navy to control ships at sea suspected of carrying potential clandestine migrants, increasing the maximum detention time for irregular migrants to 60 days, and levying steeper sanctions on migrant traffickers and smugglers (Finotelli and Sciortino 2009). Despite these increased external controls and the 
law's restrictive ambition, the legislation also included yet another massive regularization program. While framed as a "humanitarian" amnesty for undocumented caretakers of children and the elderly, the program only required work documentation in the form of 3 months of pension contributions and proof of continued employment (Levinson 2005b). The program adjusted the status of 634,700 of 700,000 applicants by granting them 1-year residence permits, with a possible extension of 6 months if the migrant had lost the job and needed to look for work (Levinson 2005b). The Bossi-Fini law thus was unable to reconcile its restrictive ambitions with the structural reality of immigration to Italy, and the Berlusconi government eventually accepted the need for new workers and increased the yearly quota (Finotelli and Sciortino 2009).

Subsequent governments did not pass any major immigration legislation in the period under review. A center-left government elected in 2006 campaigned on an overhaul of the system but was unable to muster the parliamentary majority necessary to pass legislation. The return of a Berlusconi government in 2008 signaled a return to restrictionist policies, this time through the introduction of public-security measures designed to facilitate deportation of migrants convicted of certain crimes (legge 125-2008). A 2011 law (decreto-legge 89, legge 129) allowed additional governmental discretion in case-by-case expulsions of migrants found to be illegally residing in Italy. According to Finotelli and Sciortino (2009),these kinds of restrictionist measures are in keeping with the trend in Italian immigration policy, which has increasingly focused on external control while ignoring the structural mechanisms - such as the size of the Italian informal economy - that sustain irregular migration in Italy. In addition, Italy's quota system acts as a de facto amnesty by allowing irregular migrants already present in Italy and working in the informal economy to apply for jobs in the formal sector and access legal status via the quota's mechanisms (Fasani 2010).

\subsection{Spain}

\subsubsection{0s-1999: European Integration}

Like Italy, Spain was traditionally a country of emigration and thus little attention was paid to legislation regulating immigration before the 1980s. Spain shares a number of other factors with Italy in the evolution of immigration policy, including the lack of a historical relationship with Senegal and many (although not all, as Latin-American migration to Spain attests) of the countries that eventually would send it migrants; recourse to frequent regularization programs as a method for dealing with recurrent irregular migration; and the economic underpinnings of large secondary and informal sectors (Reyneri 2003).

Much of Spain's legislation on internal control mechanisms arose prior to the increase in the foreign-born population in the 2000s and prior to Senegalese 
migration in the 1990s. A Franco-era decree ${ }^{3}$ took some steps to define the regulations governing the entry of foreigners: valid passports were required, and those foreigners who were required to have a visa had to apply for it prior to arrival (see Table 2.4 for a synthesis of the evolution of immigration policy in Spain). Although there is no existing list of nationalities subject to visa requirements at that time, experts have stated that Senegalese were certainly subject to this requirement. ${ }^{4}$ Unlike both France and Italy, then, Senegalese were always at least formally required to have a visa to enter Spain.

The first national-level law on immigration was passed in 1985 in response to Spain's integration into the European Community and the wariness of Spain's European neighbors regarding the permeability of its borders (Calavita 1998, 2003). The Ley Organica 7/1985 on "the rights and liberties of foreigners in Spain" required all foreigners entering Spain to have an entry visa, with exceptions for those nationals exempted under international treaties (which did not include Senegalese). Foreigners staying for longer than 90 days were required to have a residence permit (permiso de residencia), the period of validity of which could not exceed 5 years. Foreigners wishing to establish residency for work were required to submit a formal work contract from an employer and apply for a work permit (permiso de trabajo) in addition to a residence permit.

While issued by separate Ministries, the residence and work permits would be of the same duration and in the form of a single document, and both could be renewed during a single procedure. Temporary work authorizations for durations of less than 90 days did not require a residence permit but were still contingent on legal residence. The law also spelled out the legal grounds for expulsion of migrants, including lack of a residence permit or working without a work permit. This law did not, however, contain any provisions for family reunification or permanent residence (González-Enríquez 2010), although the application decree of 1986 did provide for a family-reunification visa. In addition to external and internal mechanisms of control, the law also defined the rights of foreigners, but conditioned the granting of these rights on legal residence in Spain (Calavita 1998).

These measures were thus restrictive in nature, and Calavita (1998) argues that the provisions of this law that required visas, residence permits, and work permits immediately plunged the majority of immigrants residing in Spain at that time into irregular status. The law thus also contained provisions for a regularization program, eligibility for which was conditional on migrants being able to have legitimate continuing work contracts or other formal means of support and to have resided in Spain before July 24, 1985 (Levinson 2005c). Only 44,000 migrants applied for regularization under this program (between $25 \%$ and $50 \%$ of those eligible to do so), and only 23,000 were able to successfully adjust status. The program was also criticized for making it difficult for immigrants to renew their regularized status, meaning many subsequently fell back into irregularity (Levinson 2005c).

\footnotetext{
${ }^{3} \mathrm{~A}$ decreto (decree) is an administrative action used by the executive branch to establish regulations that make it possible to carry out existing law and thus has a normative rank below that of a ley (law) (Mezger and González-Ferrer 2013).

${ }^{4}$ Amparo González-Ferrer, personal communication, November 15, 2012.
} 
Table 2.4 Synthesis of major immigration measures in Spain and consequences for migrant irregularity

\begin{tabular}{|c|c|c|}
\hline Date & Name of law & Consequence for irregularity \\
\hline $\begin{array}{l}\text { February } \\
14,1974\end{array}$ & $\begin{array}{l}\text { Decreto 522/1974, de } 14 \text { de febrero, por el } \\
\text { que se regula el régimen de entrada, } \\
\text { permanencia y salida de los extranjeros en } \\
\text { España }\end{array}$ & $\begin{array}{l}\text { Required valid passport and } \\
\text { pre-arrival visa for entry }\end{array}$ \\
\hline \multirow[t]{5}{*}{$\begin{array}{l}\text { July } 1, \\
1985\end{array}$} & \multirow[t]{5}{*}{$\begin{array}{l}\text { Ley Organica } 7 / 1985 \text { Sobre derechos y } \\
\text { libertades de los extranjeros en España }\end{array}$} & $\begin{array}{l}\text { Required all foreigners entering } \\
\text { Spain to have an entry visa and to } \\
\text { apply for a residence permit for } \\
\text { stays exceeding } 90 \text { days }\end{array}$ \\
\hline & & $\begin{array}{l}\text { Required submission of formal } \\
\text { work contract and work permit for } \\
\text { employment }\end{array}$ \\
\hline & & $\begin{array}{l}\text { Expulsion of migrants possible if } \\
\text { lacking residence and/or work } \\
\text { permit }\end{array}$ \\
\hline & & $\begin{array}{l}\text { Rights conditional on legal } \\
\text { residence }\end{array}$ \\
\hline & & Regularization program \\
\hline 1991 & Administrative action & Regularization program \\
\hline 1993 & Decision by Council of Ministers & $\begin{array}{l}\text { Introduced a quota system for } \\
\text { foreign workers }\end{array}$ \\
\hline \multirow[t]{3}{*}{$\begin{array}{l}\text { February 2, } \\
1996\end{array}$} & \multirow[t]{3}{*}{ Real Decreto $155 / 1996$} & $\begin{array}{l}\text { Defined multiple kinds of entry } \\
\text { visas }\end{array}$ \\
\hline & & $\begin{array}{l}\text { Made the issuance of residence and } \\
\text { work permits dependent on having } \\
\text { entered with the corresponding type } \\
\text { of visa }\end{array}$ \\
\hline & & Continued quota system \\
\hline \multirow[t]{7}{*}{$\begin{array}{l}\text { January } 11, \\
2000\end{array}$} & \multirow{7}{*}{$\begin{array}{l}\text { Ley Organica 4/ 2000: Sobre derechos y } \\
\text { libertades de los extranjeros en España y su } \\
\text { integración social }\end{array}$} & $\begin{array}{l}\text { Irregular residence and work not } \\
\text { grounds for expulsion }\end{array}$ \\
\hline & & $\begin{array}{l}\text { Granted social rights to documented } \\
\text { and undocumented migrants with } \\
\text { Padrón registration }\end{array}$ \\
\hline & & $\begin{array}{l}\text { Increased validity of temporary } \\
\text { residence and work permits to } \\
5 \text { years }\end{array}$ \\
\hline & & $\begin{array}{l}\text { Created permanent permits for } \\
\text { foreigners with } 5 \text { years of renewals } \\
\text { of temporary residence or work } \\
\text { permits }\end{array}$ \\
\hline & & $\begin{array}{l}\text { Granted temporary residence } \\
\text { permits to foreigners with two } \\
\text { uninterrupted years of residence }\end{array}$ \\
\hline & & Formalized quota system \\
\hline & & Regularization program \\
\hline
\end{tabular}


Table 2.4 (continued)

\begin{tabular}{|c|c|c|}
\hline Date & Name of law & Consequence for irregularity \\
\hline \multirow[t]{7}{*}{$\begin{array}{l}\text { December } \\
22,2000\end{array}$} & \multirow{7}{*}{$\begin{array}{l}\text { Ley Organica 8/2000: de } 22 \text { de diciembre, } \\
\text { de reforma de la Ley Orgánica } 4 / 2000 \text {, de } 11 \\
\text { de enero, sobre derechos y libertades de los } \\
\text { extranjeros en España y su integración } \\
\text { social. }\end{array}$} & $\begin{array}{l}\text { Reinstated expulsion as a sanction } \\
\text { for irregular residence or work }\end{array}$ \\
\hline & & $\begin{array}{l}\text { Increased to } 5 \text { years period of } \\
\text { continuous residence for granting of } \\
\text { temporary residence permit }\end{array}$ \\
\hline & & $\begin{array}{l}\text { Temporary residence permits were } \\
\text { contingent on possessing the } \\
\text { appropriate administrative } \\
\text { authorization to work }\end{array}$ \\
\hline & & $\begin{array}{l}\text { Renewal of work permit contingent } \\
\text { on ongoing work contract }\end{array}$ \\
\hline & & Continued quota system \\
\hline & & Regularization program \\
\hline & & $\begin{array}{l}\text { Introduced regularization for } \\
\text { arraigo }\end{array}$ \\
\hline \multirow[t]{3}{*}{$\begin{array}{l}\text { November } \\
20,2003\end{array}$} & \multirow[t]{3}{*}{ Ley Organica $14 / 2003$} & $\begin{array}{l}\text { Required foreigners to renew their } \\
\text { Padrón registration every } 2 \text { years }\end{array}$ \\
\hline & & $\begin{array}{l}\text { Required combined work and } \\
\text { residence visa for entry for work }\end{array}$ \\
\hline & & $\begin{array}{l}\text { Eliminated ability to acquire } \\
\text { residence permit based solely on } \\
\text { duration of residence, but arraigo } \\
\text { provision retained }\end{array}$ \\
\hline \multirow[t]{3}{*}{$\begin{array}{l}\text { December } \\
30,2004\end{array}$} & \multirow[t]{3}{*}{ Real Decreto 2393/2004 } & $\begin{array}{l}\text { Laid out in detail the link between } \\
\text { different categories of visas and the } \\
\text { residence and work permits }\end{array}$ \\
\hline & & $\begin{array}{l}\text { Specified the individual } \\
\text { regularization procedures associated } \\
\text { with arraigo }\end{array}$ \\
\hline & & "Normalization" program \\
\hline \multirow[t]{2}{*}{ July 2006} & \multirow[t]{2}{*}{ Plan África } & $\begin{array}{l}\text { Cooperation with migrant-sending } \\
\text { countries in matters of border } \\
\text { surveillance and readmission of } \\
\text { irregular migrants }\end{array}$ \\
\hline & & Increased development assistance \\
\hline
\end{tabular}

While no new immigration legislation would be passed before the turn of the century, the Spanish government pursued piecemeal reforms through other legal mechanisms. Due in part to the failure of the 1985 regularization program, the Spanish government, through a decision in the Council of Ministers communicated by a resolution, carried out another regularization program in 1991. Although not part of a legislative reform, this administrative action recognized the limitations of the previous approach by specifically targeting migrants who had previously possessed a residence permit; the measure thus sought to resolve some of the ambiguity introduced by the difficulty in renewing regularized status. Additional requirements were an ongoing formal work contract or self-employment in a lucrative enterprise, 
and residence in Spain prior to May 15, 1991 (Calavita 1998). Almost 110,000 migrants were regularized by this program, out of an applicant pool of 135,000 (Levinson 2005c).

The Spanish Council of Ministers again took a non-legislative route to the reform of immigration policy when it introduced a quota system for foreign workers in 1993. This initial foray defined three sectors where local labor was deemed to be lacking — agriculture, construction, and basic services—and created mechanisms by which foreign workers could be recruited to fill vacancies (Calavita 1998). The system only managed to fill 5220 of the 20,600 slots set aside, mostly because of administrative hurdles that employers were unable or unwilling to jump over (Calavita 1998). Rules were subsequently loosened, and the government continued to define a quota for foreign recruitment throughout the 1990s.

In 1996 the Spanish government issued a decree (Real Decreto 155/1996) specifying regulations for the application of the 1985 law. This decree defined multiple kinds of entry visas and made the issuance of residence and work permits dependent on having entered with the corresponding type of visa. The quota system for the recruitment of foreign labor was continued. The internal control mechanisms remained similar to those defined in the 1985 law, with the exception of the introduction of permanent residence and work permits, which could be granted to a foreigner who had lived and worked in Spain continuously and in a regular situation for at least 5 years. These permanent permits were valid for 5 years and automatically renewable. Solé and Parella (2003) argue that the introduction of these permits was an important step towards recognizing the permanent nature of immigration to Spain in that it recognized migrants' rights to settle and improve their working conditions. Finally, the decree also included a regularization program targeted specifically at foreigners who had fallen into irregularity after having gained residence and work permits through previous regularization programs (Reyneri 2003), which succeeded in adjusting the statuses of 21,300 foreigners (Levinson 2005c).

\subsubsection{0-2008: Rights and Freedoms of Foreigners, Alien Affairs, and Plan África}

The start of the twenty-first century saw a flurry of immigration legislation in Spain, and the initial trend was towards increased tolerance of irregular migrants. A new Organic Law (Ley Organica 4/2000) on the "Rights and Freedoms of Foreigners and their Social Integration" was passed by the opposition left-wing coalition in January 2000 and was mostly concerned with protecting the rights and facilitating the integration of migrants in Spain. The law recognized the enduring presence of migrants with irregular status in the country: although it defined irregular residence and work as serious infractions punishable by a fine, they were not grounds for expulsion (Calavita 2003). Additionally, the law granted a wide array of social rights to education, political participation, and health care to both documented and 
undocumented migrants as long as they were registered in the Padrón municipal (González-Enríquez 2010). This provision meant an end to the statistical invisibility of irregular migrants in Spain. Huge numbers of irregular migrants registered with the Padrón, leading to the realization that upwards of $50 \%$ of non-EU foreigners were in Spain illegally as of 2003 (González-Enríquez 2009).

For internal control, the law maintained the system of temporary residence and work permits for stays of longer than 90 day, but increased their length of validity to up to 5 years. In addition, the law created a permit for permanent residence for foreigners with 5 years of temporary residence and a permanent work permit for foreigners who had renewed temporary permits for 5 years in a row. Any foreigner with two uninterrupted years of residence in Spain could be granted a temporary residence permit, conditional on registration with the municipal authorities. In addition, the law prescribed another regularization program, open to foreigners residing in Spain before June 1, 1999 who had either possessed or applied for a residence or work permit in the three previous years. The program eventually regularized 153,463 foreigners (Levinson 2005c). The law also formalized the quota system introduced in the 1996 decree, making legal immigration for work possible, in theory.

A counter-reformation of this law came quickly, however, in the form of another Organic Law (Ley Organica 8/2000) on "alien affairs," which was approved in December 2000 and came into effect in January 2001.The center-right Popular Party had won an outright parliamentary majority in March 2000 and made the reform of the liberal immigration law from January a public issue. The reform law succeeded in rolling back some of the more lenient provisions of its predecessor: expulsion was reinstated as a sanction for irregular residence or work, and the period of continuous residence after which irregular migrants could gain a temporary residence permit was increased to 5 years from 2 . There were also changes to the system of internal control: temporary residence permits were contingent on possessing the appropriate administrative authorization to work (autorización administrativa para trabajar), while the law also stated that a residence permit was required in addition to a work permit. In addition, renewal of the work permit was only possible with an ongoing work contract.

These provisions made it more difficult for migrants, often working in the informal economy, to access residence permits and also made gaps in legal residence possible for migrants possessing a work permit. The law reaffirmed the continuation of the quota system and called for a new amnesty program targeted at those who were denied regularization during the 2000 amnesty because they had not resided in Spain prior to June 1, 1999. This re-examination resulted in the regularization of 232,674 foreigners (Kraler 2009). The law also allowed the regularization of status for reasons of "arraigo" (rootedness), and an additional regularization program between June and August adjusted the status of 13,735 foreigners, who had to prove residence in Spain prior to January 23, 2001 (Lorenzo 2002).

By 2003, the proportion of foreigners residing in Spain without a residence permit is estimated to have reached over $50 \%$, and public concern about irregular migration was growing (González-Enríquez 2009). The center-right ruling party 
and the leftist opposition agreed to another reform of the 2000 law on foreigners. This reform law (Ley Organica 14/2003) translated concerns about irregular migration into new restrictive measures. It allowed the Interior Ministry to access the data on foreigners contained in the Padrón for police purposes (although the Ministry has not yet done so), and required foreigners to renew their Padrón registration every 2 years (González-Enríquez 2009). The law specified new categories of visas, including a residence visa that precluded work and a work and residence visa for foreigners wishing to work in Spain. A work and residence visa would be necessary for the granting of an autorización administrativa para trabajar, which would allow a migrant to reside in Spain for its duration, effectively creating a single permit (even though migrants were still required to obtain residence permits). The possibility of acquiring a residence permit based on the amount of time spent in Spain (2 years in Law 4/2000, and 5 years in Law 5/2000) was eliminated completely; ongoing regularization was available only through a provision for arraigo (González-Enríquez 2009).

The socialist party won the general election in March 2004 and issued additional regulations for the application of the Foreigners Law in August of the same year (Real Decreto 2393/2004). The regulations laid out in detail the link between different categories of visas and the residence and work permits to which they were linked. Employers wishing to hire a foreigner were required to submit applications for work permits while the foreigner was abroad; the foreigner could then apply for a work and residence visa, which would allow temporary residence in Spain. The law specified the individual regularization procedures associated with arraigo, which could be for either social or work reasons. For regularization for social attachment, foreigners had to live in Spain for 3 years and prove that they had either a work contract or "social insertion" in their place of residence as certified by a report from city hall or from legal migrants to which the foreigner was related. Another provision for workplace rootedness allowed foreigners to adjust their status after living in Spain for 2 years with a labor relationship with an employer for at least 1 year.

Both of these individual regularization procedures would result in the issuance of temporary residence permits. In addition to these individual regularization mechanisms, the regulations included a "normalization" program designed to address Spain's large underground economy (González-Enríquez 2009). Employers had to apply for the regularization of their foreign workers with the guarantee of a formal contract with a validity of at least 6 months; foreigners had to be registered with the municipality and have resided in Spain for 6 months prior to the passage of law 2000/4. Carried out between February and May 2005, the program received 700,000 applications, of which 578,000 were accepted, with 550,000 signing up to begin paying into social security (Levinson 2005c). Finally, the regulations reformed the quota system once again: it emphasized hiring migrants in their country of origin and published a quarterly list of openings by province (González-Enríquez 2009). 


\section{The Arrival of the Cayucos in the Canary Islands and Spain's "Plan África"}

The year following this regularization program saw the arrival in rickety fishing boats of over 30,000 clandestine migrants on the shores of Spain's Canary Islands. The boats departed from locations on the coast of West Africa in Mauritania, Senegal, and Guinea-Bissau and carried sub-Saharan Africans as well as, in far lesser proportion, Pakistanis, Indians, Afghans, and Iraqis (Charles 2007). Spanish authorities quickly became concerned about the possibility of a massive "invasion" of undocumented Africans and rushed to put into place an "Africa Plan" (Plan África) in early 2006 that would stop this unwanted flow (Charles 2007; Gagrielli 2008). This plan included increased cooperation with migrant-sending countries in matters of border surveillance and readmission of irregular migrants in exchange for development assistance (Gagrielli 2008). An initial agreement between the Senegalese and Spanish governments in May 2006 paved the way for the repatriation of 623 Senegalese nationals identified in the Canary Islands.

The first flight containing 99 deported Senegalese migrants in handcuffs landed in Dakar in early June, and the press coverage of this event forced the Senegalese government to temporarily stop repatriations (Gagrielli 2008). The Spanish government promised a $€ 20$ million loan to Senegal on June 16, and additional deportations of 189 Senegalese migrants took place between June 19 and 24. In addition, Senegal agreed to cooperate with Spain in patrols of Senegalese territorial waters. Dakar and Madrid signed a series of formal bilateral accords in December 2006 on the emigration of minors and the fight against criminality, but were unable to conclude treaties on cooperative migration management or readmission of irregular migrants (Gagrielli 2008). The Spanish quota for 2008 included provisions for Senegalese workers, and at least 140 Senegalese were selected for 12-month work contracts in Spain between 2006 and 2007 (Charles 2007).

\subsection{Conclusion}

The evolution of immigration policies in France, Italy, and Spain demonstrates that contexts of reception for Senegalese migrants in Europe have varied widely both within these destinations over time and between these destinations. It may be useful to recall Portes's typology of negative, neutral, and advantaged contexts of reception (Portes and Böröcz 1989; Portes and Rumbaut 2006) to make sense of this variation. In France, there has been an evolution from colonial-era political and personal "assimilation" of Senegalese originaires into the French nation alongside and exclusion of other Senegalese "subjects" from the French nation; to a postindependence preferential regime that put few restrictions on the ability of Senegalese to enter, reside, or work in France; to an alignment of the bilateral relationship with Senegal with the general immigration-control regime via the gradual erosion of the preferential regime. Contexts of reception in France for Senegalese 
have thus varied from somewhat advantaged in the colonial (for originaires) and immediate postcolonial periods, to neutral with the first erosions of the preferential regime, to negative when Senegalese were fully subject to the restrictive general system of immigration control. This restrictive system has furthermore been marked by discrimination against and stigmatization of Africans (Adida et al. 2010) and somewhat blatant attempts to limit flows of migrants from Africa (Schain 2008). While France seems to have acknowledged the formerly privileged status of Senegalese in its most recent bilateral migration-management accord with Senegal, the basic parameters of the context of reception remain restrictive and negative.

The contexts of reception in Italy and Spain have differed from those in France, especially in their timing and in the imposition of immigration restrictions. Attitudes of the host society towards irregular migrants have also varied over time and between countries. These southern European contexts of reception were never advantaged for Senegalese migrants, with the possible exception of the pre-1990 period in Italy when Senegalese were exempt from visa requirements. Contexts of reception in these two countries have thus mostly been negative with regard to Senegalese migrants, in that they faced the same set of increasingly restrictive immigrationcontrol measures as most other migrants. These differences underscore the importance of incorporating multiple contexts of reception into analyses of the production and consequences of irregular migration.

Recent research on the broader evolution of immigration policy across many countries can shed light on the general evolution towards restrictiveness in the three main contexts of reception of Senegalese migrants. The DEMIG project analyzed the long-term evolution of migration policies in 45 countries between 1945 and 2014 and found that border control policies have become more restrictive, while entry and integration policies have become less so (de Haas et al. 2016). Analyses of policy evolution in OECD countries by the Immigration Policies in Comparison (IMPIC) project revealed similar trends: between 1980 and 2010 migration policies became more liberal for labor, humanitarian, and family policies but more restrictive for control measures including border crossing and irregular migration (Helbling and Kalkum 2017). These comparative projects confirm the trend towards increasing restrictiveness in some facets of the contexts of reception facing Senegalese migrants in France, Italy, and Spain.

This chapter has shown that variations in contexts of reception have produced a variety of socio-legal configurations that give rise to different pathways of irregularity. Senegalese in France had de facto regular status for much of the 1960s and 1970s in that they did not need explicit authorization to enter or reside in France and were able to take advantage of common post facto regularization procedures. Irregularity became more common among Senegalese as this preferential regime crumbled, and the massive participation of Senegalese and other Africans in the sans papiers movement in the mid-1990s highlighted the extent to which changes in immigration-control legislation had created precarity in their legal statuses.

Irregularity seems to have been a consistent component in contexts of reception in Italy and Spain, as their frequent and massive regularization programs demonstrate. Much of this irregularity seems to stem from the mismatch between restric- 
tive immigration-control measures and structural demands for cheap, low-skilled labor (Finotelli and Sciortino 2009; González-Enríquez 2009; Reyneri 2003), echoing similar dynamics in the US (Massey et al. 2002; Portes 1978).

These dynamics illustrate that irregularity is very much a manufactured state rather than a characteristic of the migrants themselves. It is produced when governments impose rules and regulations on flows that arose largely for economic reasons and were extended by social mechanisms of network formation. These legal impositions are undertaken mostly in response to shifts in domestic political sentiment over time and are uninformed by any understanding of migratory processes themselves, yielding policies and regulations that are inconsistent over time and often contradictory at any given moment, thus producing irregularity. Migration that is judged legal at one time can thus become illegal at a later date not because of any change among migrants or the basic process of immigration, but because of arbitrary shifts in policy made without regard to the practical realities of international migration.

\section{References}

Adida, C. L., Laitin, D. D., \& Valfort, M.-A. (2010). Identifying barriers to Muslim integration in France. Proceedings of the National Academy of Sciences of the United States of America, 107(52), 22384-22390.

Alaux, J.-P. (2001). À La Rue Sous Prétexte de Polygamie. Plein Droit, 51, 10.

Amin, S. (Ed.). (1972). Modern migrations in Western Africa: Studies presented and discussed at the eleventh international African seminar, Dakar, April 1972. London: published for the International African Institute by Oxford University Press.

Amin, S. (1995). Migrations in contemporary Africa: A retrospective view. In J. Baker \& T. A. Aina (Eds.), The migration experience in Africa. Uppsala: Nordiska Afrikainstitutet.

Babou, C. A. (2002). Brotherhood solidarity, education and migration: The role of the Dahiras among the Murid Muslim community of New York. African Affairs, 101(403), 151-170.

Beauchemin, C., \& González-Ferrer, A. (2011). Sampling international migrants with origin-based snowballing method: New evidence on biases and limitations. Demographic Research, 25, 103-134.

Beauchemin, C., Caarls, K., \& Mazzucato, V. (2013). Senegalese migrants between here and there: An overview of family patterns. MAFE Working Papers (MAFE Working Paper 33). Paris: INED.

Bergues, H. (1973). L'immigration Des Travailleurs Africains Noirs En France et Particulièrement Dans La Région Parisienne. Population, 28(1), 59-79.

Bredeloup, S. (1993). Les Migrants Du Fleuve Sénégal : A Quand La « Diams'pora »? Revue Européenne de Migrations Internationales, 9(3), 205-232.

Brochmann, G. (1999). The Mechanisms of control. In G. Brochmann \& T. Hammar (Eds.), Mechanisms of immigration control: A comparative analysis of European regulation policies (pp. 1-27). Oxford: Berg.

Calavita, K. (1998). Immigration, law, and marginalization in a global economy: Notes from Spain. Law \& Society Review, 32(3), 529-566.

Calavita, K. (2003). A ‘reserve army of delinquents’: The criminalization and economic punishment of immigrants in Spain. Punishment \& Society, 5(4), 399-413.

CERC-Association. (1999). Immigration, Emploi, et Chômage: Un État Des Lieux Empirique et Théorique (Vol. 3). Paris: CERC-Association. 
Charles, C. (2007). Le double jeu de l'Espagne. Plein droit, 73(2), 26-30.

Cimade, L. (2009). Les Accords Relatifs à La Gestion Concertée Des Flux Migratoires et Au Codéveloppement. Paris: La Cimade.

Coquery-Vidrovitch, C. (2001). Nationalité et Citoyenneté En Afrique Occidentale Français: Originaires et Citoyens Dans Le Sénégal Colonial. The Journal of African History, 42(2), 285-305.

Crowder, M. (1967). Senegal: A study of French assimilation policy (Revised ed.). London: Methuen. Distributed in the U.S. A. by Barnes \& Noble.

de Haas, H. (2007a). Irregular migration from Africa to Europe: Questioning the transit hypothesis. International Migration Institute.

de Haas, H. (2008a). Irregular migration from West Africa to the Maghreb and the European Union: An overview of recent trends. Geneva: International Organization for Migration.

de Haas, H., Natter, K., \& Vezzoli, S. (2016). Growing restrictiveness or changing selection? The nature and evolution of migration policies. International Migration Review. https://doi. org/10.1111/imre.12288.

Dedieu, J.-P. (2011). Associations subsahariennes : de la liberté d'association à la liberté surveillée. Plein droit, 89, 32-36.

di Friedberg, O. S. (1993). L'immigration Africaine En Italie: Le Cas Sénégalais. Etudes Internationales, 24(1), 125-140.

Diop, M. (1993). L'immigration Ouest-Africaine En Europe. Études Internationales, 24(1), $111-124$.

Donovon, V. (1988). Réalités Françaises et Conventions Franco-Africaines de Circulation Des Personnes. Peuples Noirs Peuples Africains, 59-62, 149-164.

Ebin, V. (1992). A La Recherche de 'Nouveaux Poissons.' Stratégies Commerciales Mourides Par Temps de Crise. Politique Africaine, 45, 86-99.

Fall, M. (2005). Le Destin Des Africains Noirs En France: Discriminations, Assimilation, Repli Communautaire. Paris: L'Harmattan.

Fasani, F. (2010). The Quest for La Doce Vita? Undocumented Migration in Italy. In A. Triandafyllidou (Ed.), Irregular migration in Europe: Myths and realities (pp. 115-124). Surrey: Ashgate Publishing, Ltd.

Findley, S., Traoré, S., Ouedraogo, D., \& Diarra, S. (1995). Emigration from the Sahel. International Migration, 33(3-4), 469-556.

Finotelli, C., \& Sciortino, G. (2009). The importance of being southern: The making of policies of immigration control in Italy. European Journal of Migration and Law, 11, 119.

Gagrielli, L. (2008). Flux et Contre-Flux Entre l'Espagne et Le Sénégal. L'externalisation Du Contrôle Des Dynamiques Migratoires Vers l'Afrique de l'Ouest. Revue Asylon(S) (3).

Garson, J.-P. (1992). Migration and interdependence: The migration system between France and Africa. In M. M. Kritz, L. L. Lim, \& H. Zlotnik (Eds.), International migration systems: A global approach, international studies in demography. Oxford: Clarendon Press.

GISTI. (2011). Le guide de l'entrée et du séjour des étrangers en France. Paris: la Découverte.

Gokalp, C. (1975). Chronique de l'immigration. Population, 30(4), 889-896.

González-Enríquez, C. (2009). Spain, the cheap model: Irregularity and regularisation as immigration management policies. European Journal of Migration and Law, 11, 139.

González-Enríquez, C. (2010). Spain: Irregularity as a rule. In A. Triandafyllidou (Ed.), Irregular migration in Europe: Myths and realities (pp. 115-124). Surrey: Ashgate Publishing, Ltd.

Gonzalez-Enríquez, C., \& Triandafyllidou, A. (2009). Introduction: Comparing the new hosts of southern Europe. European Journal of Migration and Law, 11, 109.

Helbling, M., \& Kalkum, D. (2017). Migration policy trends in OECD countries. Journal of European Public Policy, O(0), 1-19.

Hollifield, J. F. (1999). Ideas, institutions, and civil society: On the limits of immigration control in France. In G. Brochmann \& T. Hammar (Eds.), Mechanisms of immigration control: A comparative analysis of European regulation policies (pp. 59-95). Oxford: Berg. 
Kaag, M. (2008). Mouride transnational livelihoods at the margins of a European society: The case of residence Prealpino, Brescia, Italy. Journal of Ethnic \& Migration Studies, 34(2), 271-285.

Kabbanji, L. (2013). Towards a global agenda on migration and development? Evidence from Senegal. Population, Space and Place, 19(4), 415-429.

Kane, O. (2011). The homeland is the Arena: Religion, transnationalism, and the integration of Senegalese immigrants in America. Oxford: Oxford University Press.

Kraler, A. (2009). Regularisation: A misguided option or part and parcel of a comprehensive policy response to irregular migration? (Vol. 24). Vienna: IMPCD.

Kritz, M. M., Lim, L. L., \& Zlotnik, H. (1992). International migration systems : A global approach. Oxford/New York: Clarendon Press/Oxford University Press.

Laubenthal, B. (2007). The emergence of pro-regularization movements in Western Europe. International Migration, 45(3), 101-133.

Lessault, D., \& Beauchemin, C. (2009a). Ni invasion, ni exode. Regards statistiques sur les migrations d'Afrique subsaharienne. Revue Européenne des Migrations Internationales, 25(1), 163-194.

Levinson, A. (2005a). Regularisation programmes in France. Oxford: Centre on Migration, Policy and Society, University of Oxford.

Levinson, A. (2005b). Regularisation programmes in Italy. Oxford: Centre on Migration, Policy and Society, University of Oxford.

Levinson, A. (2005c). Regularisation programmes in Spain. Oxford: Centre on Migration, Policy and Society, University of Oxford.

Lochak, D. (1997). Les politiques de l'immigration au prisme de la législation sur les étrangers. In D. Fassin, A. Morice, \& C. Quiminal (Eds.), Les lois de l'inhospitabilité: les politiques de l'immigration à l'épreuve des sans-papiers, Cahiers libres (pp. 29-45). Paris: La Découverte.

Lorenzo, C. P. (2002). Nuestra Errática Normativa Sobre Extranjería: Especial Referencia a Las Regularizaciones y Al Arraigo. Jueces Para La Democracia, 43, 62-71.

Manchuelle, F. (1997). Willing migrants: Soninke labor diasporas, 1848-1960. Athens: Ohio University Press.

Mann, G. (2003). Immigrants and arguments in France and West Africa. Comparative Studies in Society and History, 45(2), 362-385.

Marin, L. (2006). Gêner Pour Exister : L'occupation de l'église Saint-Bernard à Paris En 1996 Par Le 'Premier Collectif' Des sans-Papiers et Ses Conséquences. Migrations Société, 18(104), 121-148.

Marot, N. (1995). L'évolution des accords franco-africains. Plein droit, 29-30, 96-99.

Massey, D. S., Durand, J., \& Malone, N. J. (2002). Beyond smoke and mirrors: Mexican immigration in an era of economic integration. New York: Russell Sage Foundation.

Mezger Kveder, C. L. (2012). Essays on migration between Senegal and Europe: Migration attempts, investment at origin and returnees' occupational status. Doctoral thesis, University of Sussex.

Mezger, C., \& González-Ferrer, A. (2013). The impol database: A new tool to measure immigration policies in France, Italy and Spain since the 1960s (Vol. 34). Paris: INED.

Miller, M. J. (1994). Towards understanding state capacity to prevent unwanted migration: Employer sanctions enforcement in France, 1975-1990. West European Politics, 17(2), 140-167.

Pascual de Sans, Angels, J. C., \& Solana, M. S. (2000). Recent immigration to catalonia: Economic character and responses. In R. King, G. Lazaridis, \& C. Tsardanidis (Eds.), Eldorado or fortress?: Migration in Southern Europe (pp. 104-124). New York: St. Martin's Press.

Portes, A. (1978). Introduction: Toward a structural analysis of illegal (undocumented) immigration. International Migration Review, 12(4), 469-484.

Portes, A., \& Böröcz, J. (1989). Contemporary immigration: Theoretical perspectives on its determinants and modes of incorporation. International Migration Review, 23(3), 606-630.

Portes, A., \& Rumbaut, R. (2006). Immigrant America: A portrait (3rd ed., rev.expanded, and update). Berkeley: University of California Press. 
Reyneri, E. (1998). The role of the underground economy in irregular migration to Italy: Cause or effect? Journal of Ethnic and Migration Studies, 24(2), 313.

Reyneri, E. (2003). Immigration and the underground economy in new receiving south European countries: Manifold negative effects, manifold deep-rooted causes. International Review of Sociology, 13(1), 117-143.

Reyneri, E. (2004). Immigrants in a segmented and often undeclared labour market. Journal of Modern Italian Studies, 9(1), 71-93.

Riccio, B. (2001). From 'ethnic group' to 'transnational community'? Senegalese migrants' ambivalent experiences and multiple trajectories. Journal of Ethnic and Migration Studies, 27, 583-599.

Riccio, B. (2008). West African transnationalisms compared: Ghanaians and Senegalese in Italy. Journal of Ethnic \& Migration Studies, 34(2), 217-234.

Schain, M. A. (2008). The politics of immigration in France, Britain, and the United States: A comparative study. Basingstoke: Palgrave Macmillan.

Schoumaker, B., Flahaux, M.-L., Schans, D., Beauchemin, C., Mazzucato, V., \& Sakho, P. (2013). Changing patterns of African migration: A comparative analysis. MAFE Working Paper 18 (Vol. 18). Paris: INED.

Sciortino, G. (1999). Planning in the dark: The evolution of Italian immigration control. In G. Brochmann \& T. Hammar (Eds.), Mechanisms of immigration control: A comparative analysis of European regulation policies (pp. 233-260). Oxford: Berg.

Sciortino, G. (2004). Between phantoms and necessary evils. Some critical points in the study of irregular migrations to Western Europe. In A. Böcker, B. de Hart, \& I. Michalowski (Eds.), IMIS-beiträge: Migration and the regulation of social integration. Osnabrück: Institut für Migrationsforschung und Interkulturelle Studien (IMIS).

Solé, C., \& Parella, S. (2003). The labour market and racial discrimination in Spain. Journal of Ethnic and Migration Studies, 29(1), 121-140.

Spire, A. (2005). Etrangers à la carte: L'administration de l'immigration en France (1945-1975). Paris: Grasset.

Tall, S. M. (2008a). La Migration International Sénégalaise: Des Recrutements de Main-d'oeuvre Aux Pirogues. In M.-C. Diop (Ed.), Le Sénégal Des Migrations: Mobilités, Identités Et Sociétés, Hommes et sociétés (pp. 37-67). Paris: Karthala.

Tapinos, G. (1965). Chronique de l'immigration. Population, 20(4), 675-686.

Terray, E. (2006). Saint-Bernard, Un Bilan : Dix Ans Après. Migrations Société, 18(104), 91-102. Viet, V. (1998). La France immigrée: construction d'une politique, 1914-1997. Paris: Fayard.

Weil, P. (1995). La France et ses étrangers: l'aventure d'une politique de l'immigration de 1938 à nos jours. Paris: Gallimard.

Wihtol de Wenden, C. (2002). Les Sans-Papiers. Regards Sur l'actualité, 277, 43-53.

Open Access This chapter is licensed under the terms of the Creative Commons Attribution 4.0 International License (http://creativecommons.org/licenses/by/4.0/), which permits use, sharing, adaptation, distribution and reproduction in any medium or format, as long as you give appropriate credit to the original author(s) and the source, provide a link to the Creative Commons licence and indicate if changes were made.

The images or other third party material in this chapter are included in the chapter's Creative Commons licence, unless indicated otherwise in a credit line to the material. If material is not included in the chapter's Creative Commons licence and your intended use is not permitted by statutory regulation or exceeds the permitted use, you will need to obtain permission directly from the copyright holder.

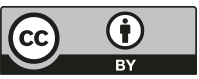

